\title{
Nog maar net...
}

Citation for published version (APA):

van Kerrebroeck, P. E. V. A. (1997). Nog maar net... maar toch. Maastricht University. https://doi.org/10.26481/spe.19971031pk

Document status and date:

Published: 31/10/1997

DOI:

10.26481/spe.19971031pk

Document Version:

Publisher's PDF, also known as Version of record

\section{Please check the document version of this publication:}

- A submitted manuscript is the version of the article upon submission and before peer-review. There can be important differences between the submitted version and the official published version of record.

People interested in the research are advised to contact the author for the final version of the publication, or visit the DOI to the publisher's website.

- The final author version and the galley proof are versions of the publication after peer review.

- The final published version features the final layout of the paper including the volume, issue and page numbers.

Link to publication

\footnotetext{
General rights rights.

- You may freely distribute the URL identifying the publication in the public portal. please follow below link for the End User Agreement:

www.umlib.nl/taverne-license

Take down policy

If you believe that this document breaches copyright please contact us at:

repository@maastrichtuniversity.nl

providing details and we will investigate your claim.
}

Copyright and moral rights for the publications made accessible in the public portal are retained by the authors and/or other copyright owners and it is a condition of accessing publications that users recognise and abide by the legal requirements associated with these

- Users may download and print one copy of any publication from the public portal for the purpose of private study or research.

- You may not further distribute the material or use it for any profit-making activity or commercial gain

If the publication is distributed under the terms of Article $25 \mathrm{fa}$ of the Dutch Copyright Act, indicated by the "Taverne" license above, 
Universiteitsbibliatheek

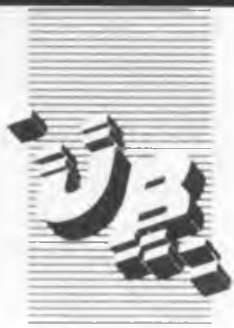

De uitleentermijn verstrijkt op:

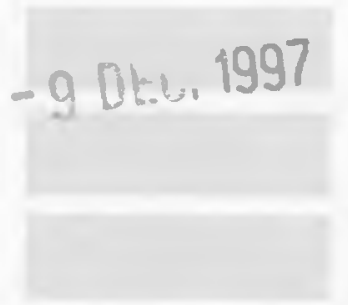

Universiteit Maastricht

Postbus 616

6200 MD Maastricht

Gelieve deze publicatie tijdig te retourneren of (telefonisch) verlenging van de uitleentermijn aan te vragen. 
NOG MAAR NET...

\section{MAAR TOCH}

Rede in verkorte vorm uitgesproken bij het aanvaarden van het ambt van buitengewoon hoogleraar in de Urologie in het bijzonder de Neuro-Urologie aan de Universiteit Maastricht op vrijdag 31 okrober 1997 


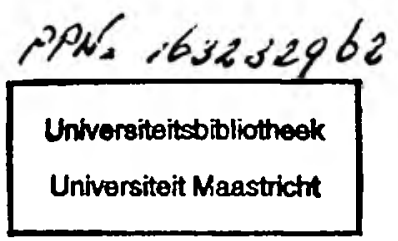

Hoe komt het toch dat Duchenne op een goede ochrend een ziekte ontdekte die waarschijnlijk al bestond in de tijd van Hippocrates? ... Waarom zien wij de dingen pas zo laat, zo slecht, met zoveel moeite? Waarom moeten we twintig keer met dezelfde symptomen geconfronteerd worden voordat we ze begrijpen? Waarom laat de eerste mededeling van wat een nieuw feit lijkt te zijn ons altijd zo koud? Omdat onze hersenen iets moeten verwerken dat tegen al onze oorspronkelijke ideeën indruist, en zo zijn we allemaal in dit ondermaanse. ${ }^{\mathrm{NI}}$

J.M. Charcot, 1872. 


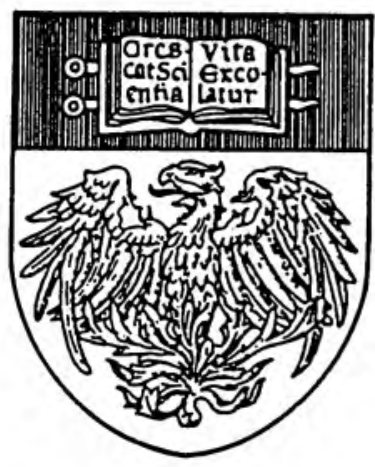

Crescat scientia, vita excolatur

Voor Kristin, Egmond, Helena, Bavo, Katarina, Teresa 
Nog maar net heeft de Neuro-Urologie een aparte plaats verkregen als sub-specialisme binnen de Urologie maar toch moet dit onderdeel van de Urologie een belangrijke rol gaan vervullen binnen het geheel van de urologische pathologie, diagnostiek en therapie.

Mijnheer de Rector Magnificus,

Dames en Heren Leden van het Universiteitsbestuur,

Dames en Heren Leden van de Universiteitsraad,

Dames en Heren Hoogleraren, Docenten en Leden van de Wetenschappelijke staf,

Dames en Heren Leden van de Raad van Bestuur en Directie van het academisch ziekenhuis Maastricht,

Dames en Heren Leden van de Medische, Technische en Administratieve Staf,

Dames en Heren Studenten,

en voorts gij allen die door uw aanwezigheid van uw belangstelling blijk geeft,

Zeer geachte toehoorders,

Met het instellen van deze eerste leerstoel in de Neuro-Urologie in Nederland en wellicht zelfs in Europa realiseert de Universiteit Maastricht (UM) en het academisch ziekenhuis Maastricht (azM) een belangrijke primeur. Toch was het instellen van deze leerstoel omwille van verschillende redenen niet evident. Ik kom daar verder in deze rede op terug.

Misschien had $U$ zich afgevraagd waarop de titel van deze rede sloeg. Met de eerste zin hoop ik $U$ alvast de plaats van de Neuro-Urologie te hebben aangegeven zoals ik deze zie en de taak die ik mezelf daarbij gesteld heb. I $\mathrm{k}$ wil echter in de rest van deze rede uitgebreider ingaan op wat de Neuro-Urologie nu eigenlijk is, wat de plaats van de NeuroUrologie binnen de Universiteir Maastricht en het academisch ziekenhuis Maastricht zou kunnen zijn en welke rol wij voor onszelf daarbij zien. Ik gebruik hier bewust het persoonlijk voornaamwoord wij. Niet als 'pluralis majestatis', maar omdat ik er mij terdege van bewust ben dat deze taak een kwestie is van meerdere mensen en niet van mij alleen. Een sub-titel voor deze rede zou kunnen zijn 'Neuro-Urologie: verleden, heden en toekomst van een urologisch sub-specialisme'. Ik wil U daarom 
dan ook meenemen naar de inhoud van de Neuro-Urologie, de historiek, de actualiteit ervan en $U$ mijn visie geven op de toekomst van de Neuro-Urologie. 


\section{Inleiding}

Dysfunctie van de lage urinewegen treedt op bij ongeveer $10 \%$ van de westerse bevolking. Een belangrijk gedeelte van deze afwijkingen wordt veroorzaakt door het slecht of ongecoördineerd functioneren van het centrale en/of perifere zenuwstelsel. Ook afwijkingen van de intrinsieke zenuwen of de ganglia van de blaas en de urethra zelf kunnen verantwoordelijk zijn voor functiestoornissen van de lage urinewegen. Verder spelen dysfuncties van de bekkenbodem een rol bij deze pathologie. Het geheel van deze afwijkingen kan gevat worden onder de algemene benaming 'Neurogeen blaaslijden' en wordt bestudeerd en behandeld binnen de 'Neuro-Urologie'. Incontinentie voor urine vormt één van de voornaamste symptomen bij mensen met neurogeen blaaslijden doch urineweginfecties en steenvorming zijn eveneens frequent voorkomende problemen met medische consequenties. Afhankelijk van de ernst van de functionele afwijkingen zullen op korte of lange termijn ook structurele afwijkingen optreden ter hoogte van de lage urinewegen. Uiteindelijk kan dit leiden tot structurele veranderingen ter hoogte van de hoge urinewegen met nierfunctieverlies en eventueel zelfs nierinsufficiëntie tor gevolg.

Verschillende vormen van neurogeen blaaslijden kunnen onderscheiden worden. Ongeveer $1 \%$ van de mensen met een slechte werking van de lage urinewegen heeft een evidente neurologische aandoening (aangeboren, traumatisch of verworven). De blaasproblematiek is hierbij een min of meer belangrijk onderdeel van het gehele ziektebeeld. Bij een wat moeilijker te definiëren groep patiënten treft men echter functieveranderingen van de blaas aan die berusten op occulte, subklinische neurologische letsels die alleen met gevoelige en vaak gesofisticeerde tests aangetoond kunnen worden.

Het klinische beeld van het neurogeen blaaslijden komt dus voor bij een verscheidenheid van ziekrebeelden. Ieder van deze aandoeningen kan echter verschillend zijn zowel wat betreft etiologie, symptomatologie als prognose. Ondanks de uitgebreide literatuur is er nog steeds geen eensgezindheid omtrent de meest adequate indeling van het neurogeen blaaslijden. Verfijnde diagnostische methodes hebben trouwens andere 
inzichten opgeleverd die nieuwe classificaries noodzakelijk maakten. Bovendien zijn nieuwe behandelingsconcepten ingevoerd, mede op basis van betere informatie over de prognose van het neurogeen blaaslijden.

Voor het bestuderen van de urologische problematiek bij neurologische patiënten kan uitgegaan worden van het neurologische ziektebeeld waarmede een bepaalde patiënt bekend is. Het verloop van deze ziekte zal immers medebepalend zijn voor de urologische problematiek en de therapeutische mogelijkheden.

Het opstellen van een adequaat behandelplan vereist bij deze patiënten vaak specifieke informatie over de aanwezige afwijkingen van de lage en hoge urinewegen. Hiervoor is uitgebreid en gespecialiseerd onderzoek nodig, evenals een medische infrastructuur waarbinnen ervaring bestaat met alle diagnostische en therapeutische, ook chirurgische, mogelijkheden.

De verzorging van dergelijke patiënten vereist dus meestal een gespecialiseerde (academische) omgeving en bovendien de aanwezigheid van specifieke neuro-urologische expertise.

Naast de functiestoornissen die evident gerelateerd zijn aan een neurologisch ziektebeeld, komen een ganse waaier van afwijkingen voor met een belangrijke weerslag op het functioneren van de lage urinewegen en de geslachtsorganen, waarbij geen duidelijk verband bestaat met een evident aanwijsbare neurologische oorzaak. Ook deze afwijkingen en aandoeningen vallen onder het aandachtsgebied van de Neuro-Urologie. Hierbij moet gedacht worden aan de verschillende vormen van incontinentie, aan ingewikkelde mictieproblematiek en ook aan meer raadselachtige aandoeningen zoals 'interstitiële cystitis', een ontstekingsproces in de wand van de blaas zonder duidelijk aanwijsbare oorzaak.

Recente inzichten in de pathofysiologie van het prostaatlijden hebben bovendien geleid tot het concept van functionele obstructie en de daarmee samengaande symptomen (Lower Urinary Tract Symptoms, LUTS of lage urinewegsymptomen). Verder hebben ook recidiverende vormen van urineweginfecties vaak een verband met functiestoornissen van de urinewegen. Hierdoor behoort ook deze problematiek strikt gesproken tot het gebied van de Neuro-Urologie. 
Tot zeer recent werden de funcriestoornissen van de lage urinewegen vooral benaderd vanuit een anatomisch perspectief. Hierbij werd hoofdzakelijk gekeken naar afwijkingen in de structuur met name met oog op het chirurgisch herstel hiervan. Deze houding werd waarschijnlijk mede ingegeven door het feit dat de urologen, als enigen van de chirurgische specialisten, het volledige traject van diagnostiek tot chirurgische therapie in eigen beheer hebben gehouden en ook zelf uitvoeren. De chirurgische overmoed van het 'alles kunnen behandelen met een operatie' heeft daardoor waarschijnlijk geleid tot deze aanpak waarbij anatomisch herstel op de voorgrond stond. Geleidelijk aan, mede door het perfectioneren van het bestuderen van het gedrag van de urinewegen door middel van verfijnde diagnostische technieken, ontstond het besef dat de urinewegen een dynamisch geheel zijn met specifieke functies.

Bovendien moeten de onderscheiden elementen van de urinewegen in een bepaalde synergie samenwerken om een normaal gedrag mogelijk te maken. Zo ontstond de interesse voor de pathofysiologie van de urinewegen waarbij vooral aandacht besteed werd aan de lage urinewegen gezien het klinische belang ervan. Vanuit de studie van de afwijkende functie van de urinewegen ontstond vervolgens interesse voor de normale functie van het urogenitale stelsel. De laatste jaren is veel vooruitgang geboekt bij het ontrafelen van de fysiologie, wederom vooral van de lage urinewegen. Vooruitgang werd niet alleen geboekt op het niveau van de studie van het gedrag van de urinewegen zelf maar ook op het niveau van de neuro-anatomie en de neurofysiologie van de controle van de lage urinewegen en dit zowel op centraal als perifeer niveau.

Merkwaardig hierbij is dat met name nieuwe behandelingsmethodes, zoals de neuromodulatie ${ }^{\mathrm{N} 2}$, de aanzet geweest zijn voor het bestuderen van de besturing van de lage urinewegen en de effecten van de hogergenoemde behandelingstechnieken hierop. Gaandeweg werd het zo mogelijk om het afwijkend gedrag van de urinewegen te onderzoeken en ook dynamisch bij te sturen. Bovendien blijkt nu dat het met deze technieken niet alleen mogelijk is om de dysfunctie van de urinewegen te normaliseren, maar dat door deze vorm van behandeling op termijn structuurafwijkingen gecorrigeerd kunnen worden. Dit is het gevolg van de plasticiteit van de (neuro-)anatomische structuren.

Slechts de laatste jaren is het duidelijk geworden dat de lage urinewegen niet kunnen benaderd worden zonder rekening te houden met de omgevende elementen en dan vooral de bekkenbodem. Het realiseren van 
de rol die deze zeer belangrijke spiergroep speelt bij het functioneren en dus ook het dysfunctioneren van de lage urinewegen heeft bovendien totaal nieuwe therapeutische perspectieven geopend.

Tengevolge van de grotendeels gemeenschappelijke innervatie van de lage urinewegen, het distale gedeelte van het rectum, het anale kanaal en de sexuele organen, zullen vele patiënten met functiestoornissen van de lage urinewegen ook te kampen hebben met samengaande fecale incontinentie, defecatiestoornissen, sexuele funcriestoornissen en eventueel fertiliteitsproblematiek. Bovendien zijn vaak gemeenschappelijke oorzaken aanwezig. Een geïntegreerde aandacht en aanpak is derhalve noodzakelijk in het kader van de Neuro-Urologie.

Toch heeft de Neuro-Urologie nog steeds een ondergeschikte positie binnen het geheel van de Urologie. Tot zeer recent werden funcriestoornissen van de urinewegen eerder als een luxe probleem beschouwd, immers uitsluitend gerelateerd aan de kwaliteit van leven. De studie en de behandeling van deze afwijkingen en verder wetenschappelijk onderzoek op dit gebied kreeg derhalve minder aandacht en proportioneel ook minder financiële middelen dan de meer herö̈sche onderdelen van de urologie zoals de oncologische urologie. Zeer recent is hierin verandering gekomen. Op verschillende niveaus binnen de structuren die onze gezondheidszorg beheren is het belangrijke medische en maatschappelijke impact van functiestoornissen van de urinewegen doorgedrongen. Het beantwoorden van de vraag naar betere zorg en uitbreiding van het wetenschappelijk onderzoek is dan ook één van de grootste uitdagingen voor allen die betrokken zijn bij de verdere ontwikkeling van de NeuroUrologie. 


\section{Geschiedenis van de Neuro-Urologie ${ }^{1}$}

Het feit dat mijn vader een historicus was en steeds aangaf dat men het heden niet kan kennen zonder de studie van het verleden, doet mij nu terugkijken naar de historiek van de Neuro-Urologie. De observatie en de studie van deze afwijkingen zijn immers geen recente ontwikkeling maar zijn reeds eeuwenlang een onderwerp dat aandacht kreeg.

De oudste vermelding van een neuro-urologisch ziektebeeld komt uit Egypte en dateert van 1500 vóór Chr. ${ }^{\mathrm{Ll}}$ In de Edwin Smith papyrus wordt een nauwkeurige beschrijving gegeven van de symptomen van een man met een complete dwarslaesie, inclusief het priapisme ${ }^{\mathrm{N} 3}$ en de overloopincontinentie. ${ }^{\mathrm{N} 4}$ Claudius Galenus (130-200) beschrijft als eerste de spiervezels van de blaas en de sphincters van de urethra, op basis van onderzoek bij dieren. Rufus van Efese ( $2^{c}$ eeuw na Chr.) vermeldt vrij gedetailleerd de verlamming van de blaas bij neurologische aandoeningen. De vlaming van de Spieghel (1578-1625) beschrijft de blaasspier en gebruikt als eerste de aanduiding 'detrusor'. De amsterdamse chirurgijn Nicolaas Tulp (1593-1674), o.a. bekend door het schilderij van Rembrandt, vermeldt in 1652 de plasproblemen die optreden bij kinderen die geboren werden met een spina bifida (open rug). Bovendien geeft hij aan dat tabes dorsalis tengevolge van tertiaire syfilis tot blaasproblemen aanleiding geeft. In 1878 zal Guy de Maupassant (1850-1893) een meer poëtische beschrijving geven van zijn blaasproblemen tengevolge van syfilis en tenslotte tabes dorsalis. Hij lijdt aan progressieve blaasstoornissen en kan tenslotte gedurende 36 uur niet plassen. Hij ontwikkelt een overloopincontinentie en beschrijft de druppels urine die afvloeien als een "stroom van diamanten". Ook Heinrich Heine (1797-1856) had syfilis en vertoonde een progressieve verlamming van blaas en darmen. Hij had gedurende 8 jaar neuro-urologische problemen en overleed tenslotte op 59jarige leeftijd tengevolge van de verwikkelingen hiervan. De eigen beschrijving van zijn sympromen wijst echter achteraf eerder in de richting van Multiple Sclerose dan van tabes dorsalis ten gevolge van syfilis.

1 Gebruik werd gemaakt van her hoofdstuk "Historical background" uit Hald T, Bradley WE: The urinary bladder. Neurology and dynamics. Williams \& Wikins, Baltimore/London, 1982. 
De van oorsprong duitse doch in Nederland werkzame chirurg Laurens Heister (1683-1758) publiceert in 1755 het boek "Heelkundige voorlezingen". Hierin bevindt zich een hoofdstuk "Over de tegenwillige afloop van de pis bij mannen". Dit is in feite de eerste neuro-urologische publicatie in het Nederlands. In dit hoofdstuk wordt o.a. ook gesproken over de verlamming van de blaas tengevolge van aandoeningen van het zenuwstelsel. Als therapie bij blaasproblemen beveelt hij aftreksel van pissebedden en van chinese paardestaart aan. Deze bevatten efedrine en kunnen dus inderdaad wel enig effect gehad hebben. ${ }^{\mathrm{NS}}$ Overigens is het dezelfde Heister die voor het eerst een penisklem ontwikkelde om ongewenst urineverlies bij de man tegen te gaan.

In de eerste helft van de $19^{c}$ eeuw vinden we voornamelijk klinische beschrijvingen van het samengaan van neurologische ziektebeelden met urologische afwijkingen. Zo beschrijft een griekse legerarts in 1857 het samengaan van haargroei laag ter hoogte van de rug met een spina bifida occulta (een open rug met gesloten huid) en plasproblemen. In datzelfde jaar beschrijft Virchow (1821-1902) dezelfde combinatie en wel bij een familie waarvan vele leden lijden aan enuresis nocturna (bedplassen). In de tweede helft van de $19^{\circ}$ eeuw wordt grote vooruitgang geboekt op het gebied van de neuro-anatomie en de neurofysiologie van de lage urinewegen. Met name het werk van Brown-Sequard (1818-1894), die een nauwkeurige beschrijving geeft van de innervatie van de lage urinewegen en van Julius Budge (1811-1888), die in 1864 het 'centrum vesicale' beschrijft onderaan het ruggemerg, zijn belangrijk. ${ }^{\text {L2 }}$

Dat de mictie gecontroleerd werd door een reflexsysteem was reeds op het einde van de $19^{\circ}$ eeuw bekend maar er was nog zeer weinig onderzoek verricht naar de centrale controle van de urinewegen. Elliot was de eerste om de rol van het sympathische zenuwstelsel te vermelden bij verschillende diersoorten. ${ }^{\mathrm{L} 3}$ Het is echter vooral Barrington (1884-1956) die in een reeks van interessante dierexperimenten de basis legde voor de moderne neurofysiologie van de lage urinewegen. ${ }^{\mathrm{L} / 4}$

De precieze anatomie van de lage urinewegen werd in het begin van deze eeuw duidelijk ${ }^{15}$ maar het duurde nog tot de vijftiger en zestiger jaren vooraleer, door het werk van Lapides en Woodburne, het misconcept van de niet bestaande interne sphincter kon weerlegd worden. ${ }^{\mathbf{L G}, \mathbf{L 7}}$ Van nog recentere datum is de microscopische studie van deze structuren. Het is slechts door het toepassen van specifieke kleuringstechnieken 
voor de belangrijkste neurotransmitters (acetylcholine en noradrenaline) dat een betere correlatie tussen functie en structuur mogelijk was. ${ }^{\text {L }}$ Het begin van de $20^{\circ}$ eeuw is ook gekenmerkt door meer interesse in de pathofysiologie van de lage urinewegen. Met name de studie van het gedrag van de blaas van gewonden met een dwarslaesie uit de eerste wereldoorlog, leverde veel informatie op. ${ }^{.9}$ Denny-Brown beschreef als eerste hoe een perifeer gedenerveerde blaas functioneert. ${ }^{\text {L10 }}$

Terzelfdertijd werden diagnostische methoden ontwikkeld om het gedrag van de lage urinewegen te registreren. De eerste die de vullingsfase van de mictiecyclus van de blaas beschreef was Dubois in 1876. ${ }^{\mathrm{L} 11} \mathrm{Het}$ duurde echter tot 1927 eer Rose een bruikbare methode beschreef om de druk in de blaas te meten, die leidde tot de ontwikkeling van de Lewis cystometer. ${ }^{\mathrm{N} 6 . \mathrm{L} 12}$ In de zestiger jaren werden cystometers ontwikkeld die de druk electronisch registreerden. ${ }^{\mathrm{L} 13}$ Een volgende uitbreiding van de urodynamische mogelijkheden betrof de toevoeging van electromyografie (EMG) van het dwarsgestreepte spierweefsel van de sphincters en de bekkenbodem. ${ }^{\text {L14 }}$

De techniek van het opwekken van electrische potentialen ter hoogte van structuren die via reflexbogen met de lage urinewegen in verbinding staan, was een belangrijke aanvulling bij de studie van de lage urinewegen maar kwam slechts in de 80-er jaren ter beschikking voor klinische toepassing. ${ }^{\text {LIS }}$

Het eenvoudig gadeslaan van de urinestroom om een idee te vormen over de kwaliteit van de mictie, is waarschijnlijk eeuwenlang een belangrijke bezigheid geweest. De eerste klinisch bruikbare methode om de urinestroom te meten werd ontwikkeld door Drake die een roterende stroommeter voorstelde. ${ }^{\mathrm{L}}{ }^{16} \mathrm{De}$ vader van de moderne urodynamica is Bodo von Garrelts (1914-1994) uit Stockholm. Hij combineerde de mering van de blaasdruk met gelijktijdige meting van de urinestroom. ${ }^{\mathrm{L} 17}$ Later voegde Scott hier nog het EMG aan toe en zette het eerste urodynamische laboratorium op. ${ }^{\text {L18 }}$ Enhörning, Miller en Hinman combineerden het urodynamisch onderzoek met roentgendoorlichting om te komen tot het volledige scala van testen zoals we het heden ten dage ook nog kennen. ${ }^{\mathrm{L}} 9$ Zinner beschreef in 1969 een methode om de mictie te bestuderen door middel van de druppelspectrometrie. ${ }^{.20}$ Dit was de eerste vorm van nietinvasief urodynamisch onderzoek.

Het meten van de druk in de urethra door middel van retrograde urethrale perfusie werd geperfectioneerd door Bors ${ }^{\text {L21 }}$ en betrouwbaar 
gemaakt voor klinische toepassing door Enhörning. ${ }^{\text {22 }}$ De methode van urethrale profilometrie werd geïntroduceerd door Brown en Wickam in $1969^{\mathrm{L} 23}$ en in 1976 werd het gebruik van de micro-tip transducer voor het eerst beschreven door Ulmsten en Rasmussen. ${ }^{24}$

Ook de behandeling van neuro-urologische stoornissen onderging een geweldige evolutie. Het duurde echter tor de tweede wereldoorlog vooraleer de moderne neuro-urologische behandelingstechnieken beschikbaar waren. Dank zij de inspanningen van Sir Ludwig Guttman werd in 1944 in Stoke Mandeville (UK) de eerste gespecialiseerd dwarslaesieafdeling ter wereld geopend. ${ }^{\text {L2S }}$ Hierbinnen werd bijzondere aandacht besteed aan de noodzakelijke maatregelen om de persoon met een dwarslaesie zo optimaal mogelijk te laten functioneren. Van dan af werd ook het belang onderkend van de urologische problematiek en de invloed op de morbiditeit en zelfs mortaliteit. Nieuwe technieken, zoals de intermittente catheterisatie, werden op grote schaal en systematisch toegepast en brachten een belangrijke verbetering van de levensverwachting en comfort voor de patiënten met een dwarslaesie met zich mee. ${ }^{\mathrm{L} 6}$ Naar analogie met deze gespecialiseerde centra voor mensen met een dwarslaesie werden in een aantal landen ook aparte centra opgezet voor mensen met andere ziektebeelden zoals bijvoorbeeld Multiple Sclerose. De techniek van de intermittente catheterisatie kreeg later dank zij het werk van Lapides een nog bredere toepassing door het ontwikkelen van de techniek van de zogenaamde 'schone zelfcatheterisatie'. ${ }^{\text {27 }}$

De functionele reëducatie als therapeutisch principe is populair geworden dank zij de publikaties van Kegel. Deze duitse gynaecoloog had vastgesteld dat Bantoe-vrouwen, ondanks multiple bevallingen, geen incontinentie hebben dankzij de goede kwaliteit van hun bekkenbodem. Op basis van het idee dat het mogelijk is om het dwarsgestreepte spierweefsel van de bekkenbodem te trainen ontwikkelde hij de oefeningen die nu zijn naam dragen. ${ }^{2.28}$

In de zestiger jaren werden intra-anale en intravaginale sondes ontwikkeld om niet-invasieve electrische stimulatie van de bekkenbodem mogelijk te maken. ${ }^{\text {L29 }}$ Door experimenten met deze intravaginale stimulatie bleek bovendien dat stimulatie van de nervus pudendus een inhibitie kan veroorzaken van instabiele detrusorcontracties. ${ }^{130}$ Deze bevindingen vormen de basis voor de roepassing van de foramen stimulatie van de sacrale zenuwwortels, de 'neuromodulatie'. 
Reeds vanaf de jaren 50 van deze eeuw bestond grote belangstelling voor het toepassen van electrische stimulatie van de blaas en de urethra, met de bedoeling om zowel de controle over de continentie als over de mictie te herstellen. De ontwikkeling van de transistor maakte, kort na de tweede wereldoorlog, de ontwikkeling van een stimulator voor hartspierstimulatie (pacemaker) mogelijk. Kort hierna startten experimenten om ook een 'blaaspacemaker' te ontwikkelen. ${ }^{\text {L11 }}$ Verschillende systemen werden ontwikkeld, met wisselend doch nooit blijvend succes. Een belangrijke nieuwe fase werd ingezet in het begin van de zeventiger jaren toen, ieder op zijn manier, Giles Brindley in Londen en Emil Tanagho in San Francisco begonnen met experimenten om een bruikbaar systeem voor functionele electrostimulatie van de blaas te ontwikkelen. ${ }^{\text {L2.133 }}$ Beide kunnen dan ook terecht als de pioniers van bruikbare systemen voor de electrostimulatie van de blaas beschouwd worden.

De actuele mogelijkheden van de micro-electronica en de moderne biomedische technieken bieden ongekende mogelijkheden ter verbetering van de huidige electrostimulatiesystemen. Belangrijke veranderingen en een spectaculaire evolutie op het gebied van de functionele electrostimulatie mogen dan ook verwacht worden. Hierop wordt verder in deze rede ingegaan wanneer de toekomstperspectieven binnen de Neuro-Urologie voorgesteld worden.

Twee verenigingen werden opgericht die de Neuro-Urologie als hun aandachtsgebied beschouwen. De International Continence Society (ICS) is in opzet een europese vereniging die echter leden telt over de ganse wereld. De Urodynamics Society (UDS) is uitsluitend in de Verenigde Staten van Amerika actief doch aanvaardt ook leden vanuit de rest van de wereld.

Door een comité van de ICS werd een standaardisatie rapport opgesteld betreffende de urodynamische terminologie en technieken. ${ }^{\text {L34 }}$ Recent werd het initiatief genomen om ook een grondige evaluatie van de resultaten van diagnostiek en therapie binnen de Neuro-Urologie op te zetten. Hierbij zullen we vanuit Maastricht zeer nauw betrokken zijn. Deze activiteiten van definiëren en standaardiseren van een aantal technieken zijn immers zeer belangrijk voor de vooruitgang van de NeuroUrologie. 


\section{Epidemiologie van de neuro-urologische pathologie en de diagnostische en therapeutische mogelijkheden}

\section{Epidemiologie van de neuro-urologische pathologie}

De incidentie en de ernst van neuro-urologische pathologie bij verschillende neurologische ziektebeelden varieert zeer sterk. Bovendien zijn er voor West-Europa weinig epidemiologische gegevens beschikbaar betreffende de incidentie en prevalentie van neuro-urologische pathologie.

Om een indruk te hebben over het belang van deze problematiek in Nederland is het nodig een extrapolatie te maken op basis van gegevens uit omringende landen. Voor enkele aandoeningen zijn voor Nederland beperkte epidemiologische gegevens beschikbaar.

Bij mensen met een dwarslaesie heeft ongeveer $75 \%$ ernstige en soms levensbedreigende neuro-urologische problemen. $\mathrm{Bij} 100 \%$ van deze patiënten is echter het delicate evenwicht van de lage urinewegen verstoord, wat leidt tot functie-afwijkingen met belangrijke consequenties voor de kwaliteit van leven van deze gehandicapte patiëntengroep. ${ }^{\text {L35 }}$ Per jaar lopen in Nederland ongeveer 450 mensen een dwarslaesie op. Meestal gaat het om jonge mensen met een goede prognose wat betreft overleving. Het totale aantal mensen met een dwarslaesie is niet bekend maar wordt geschat op ongeveer 10.000. Een nauwkeurige en in principe levenslange neuro-urologische follow-up is noodzakelijk. Bovendien is de neuro-urologische revalidatie een essentieel onderdeel van het globale revalidatieprogramma.

Bij Multiple Sclerose (MS) treden neuro-urologische problemen vroeg of laat op bij ongeveer $60 \%$ van de patiënten. Ongeveer 1 op de 1000 nederlanders wordt getroffen door deze ziekte. In totaal lijden waarschijnlijk in Nederland circa 15.000 mensen aan MS, zodat het aantal patiënten met MS en neuro-urologische problemen rond de 9.000 ligt. Deze problemen hebben belangrijke medische consequenties doch hebben tevens een belangrijk impact op de kwaliteit van leven. ${ }^{\mathbf{2} 6}$

Per jaar worden in Nederland ongeveer 450 kinderen geboren met een ernstige vorm van spina bifida. Bij de meerderheid van deze kinderen is belangrijke neuro-urologische problematiek aanwezig die vaak tot chirur- 
gisch ingrijpen noodzaakt. De incidentie van problemen ter hoogte van de hoge urinewegen is significant. Bovendien is levenslange urologische controle vereist aangezien nooit een stabiele situatie bereikt wordt.

Van de ongeveer 12.750 mensen met de ziekte van Parkinson zou ongeveer $25 \%$ blaasproblemen hebben. Bij deze mensen is incontinentie een belangrijk probleem, mede op basis van de motorische handicaps.

Van de \pm 114.000 mensen met een hersenbloeding of trombose zou ongeveer $10 \%$ ernstige blaasproblemen hebben. $\mathrm{Bij}$ deze mensen zullen met name de motorische handicaps mede de invaliditeit ten gevolge van de neuro-urologische problematiek bepalen.

Naast de neuro-urologische pathologie bij mensen met een evidente aangeboren of verworven neurologische aandoening is er nog een belangrijke groep vrouwen en mannen, kinderen en volwassenen met moeilijker te definiëren neurologische pathologie en problemen met de urinewegen.

Verder is er een gevarieerde groep patiënten met neurogene blaasproblematiek ten gevolge van lokale afwijkingen zoals na radicale chirurgie in het kleine bekken, na trauma of na radiotherapie. Bij deze mensen is vaak reconstructieve urologische chirurgie noodzakelijk om de anatomie te herstellen of te vervangen. Tot deze categorie kunnen ook mensen gerekend worden met ernstige vormen van urine-incontinentie ten gevolge van irreversiebele anatomische of functionele afwijkingen van de lage urinewegen. Ook hierbij zal meer en meer overgegaan worden tot orgaanvervangende chirurgie of tot het aanleggen van een continente urinederivatie, eerder dan toevlucht te nemen tot de klassieke incontinente urinederivatie (Bricker-derivatie).

Wanneer het aandachtsgebied van de Neuro-Urologie in brede zin gedefinieerd wordt, betreft het een zeer grote potentiële patiëntenpopulatie. Er zijn in totaal op dit ogenblik in Nederland ongeveer 750.000 mensen met een significante mate van incontinentie voor urine. Dit aantal zal door de toenemende vergrijzing nog groter worden. Ook het aantal mannen met prostatisme klachten en aanverwante of gerelateerde functiestoornissen van de lage urinewegen neemt toe. 
Over het totale aantal patiënten met ingewikkelde mictieproblematiek zijn geen goede epidemiologische gegevens beschikbaar. Gegeven de aantallen patiënten met deze afwijkingen die door de uroloog gezien worden, is hun aantal echter niet gering. Hetzelfde geldt voor patiënten met ingewikkelde recidiverende urineweginfecties.

\section{Diagnostische en therapeutische mogelijkheden}

De diagnostische en therapeutische mogelijkheden bij de neuro-urologische pathologie zijn tijdens het laatste decennium geweldig uitgebreid.

De ontwikkeling van moderne roentgenologische, echografische en isotopische onderzoeksmethoden heeft ertoe bijgedragen dat de parhofysiologie van de neurogene blaasproblematiek beter kan verklaard worden. Deze technieken laten ook toe de diagnose meer te verfijnen. Ik prijs me gelukkig binnen de muren van het academisch ziekenhuis Maastricht over al deze mogelijkheden te beschikken.

Bovendien zijn een aantal meer specifieke neuro-urologische onderzoeksmethoden ter beschikking gekomen.

Het urodynamisch onderzoek van de lage urinewegen is dankzij de beschikbare apparatuur en computerondersteuning een waardevol instrument geworden. De urodynamica heeft dan ook een sleutelrol bij de diagnostiek van de functiestoornissen van de lage urinewegen verworven. De ambulante urodynamica zoals o.a. te Maastricht ontwikkeld laat langdurige metingen toe en speelt een belangrijke rol bij de diagnostiek en de follow-up van patiënten met verschillende vormen van functiestoornissen van de lage urinewegen. Ook de urodynamica van de hoge urinewegen is verder geperfectioneerd. Deze onderzoeksmethode is een bruikbaar hulpmiddel bij de studie van de functie-afwijkingen van de hoge urinewegen en dit zowel bij primaire pathologie als bij secundaire problemen.

Het neurofysiologisch onderzoek van de lage urinewegen is een nog jong onderdeel van de neurofysiologie. In enkele gespecialiseerde centra, ook in het academisch ziekenhuis Maastricht, is deze methode echter verder uitgewerkt tot een bruikbaar instrument bij de neuro-urologische diagnostiek. 
Recent werd een nieuw element aan ons neuro-urologisch armamentarium toegevoegd, namelijk de 'Peripheral Nerve Evaluation' (PNE). Deze poliklinische test laat toe door middel van percutane electrische stimulatie van de sacrale zenuwbanen de integriteit van de innervatie van de organen in het kleine bekken aan te tonen. Bovendien kan door middel van een tijdelijk achtergelaten electrodedraad en een externe stimulator het effect van chronische electrische stimulatie op de blaas gedurende enkele dagen geëvalueerd worden. ${ }^{\mathrm{L} 37}$ Deze test is voor de neuro-uroloog zo belangrijk als de reflexhamer voor de neuroloog.

De therapeutische mogelijkheden zijn de laatste jaren eveneens sterk toegenomen. Het introduceren van het concept van de intermittente catheterisatie' d.w.z. het op regelmatige tijdstippen aftappen van de urine met een catheter en later van de 'schone intermittente zelfcatheterisatie' d.w.z. door de patiënt zelf uitgevoerd in de thuissituatie, heeft de morbiditeit en zelfs de mortaliteit bij mensen met neurogeen blaaslijden significant verminderd. ${ }^{\mathrm{L} 8}$ Bovendien hebben deze technieken tot een belangrijke verbetering van de kwaliteit van leven geleid voor grote aantallen mensen met functiestoornissen van de urinewegen.

Veel dank zijn we verschuldigd aan het farmacologisch en farmaceutisch onderzoek. Dit heeft er immers toe geleid dat uroselectieve d.w.z. meer specifiek op de urinewegen inwerkende medicatie werd ontwikkeld. Dit laat toe allerlei vormen van functiestoornissen van de urinewegen te behandelen met een maximum aan effect en een minimum aan nevenwerkingen.

Ook de reconstructieve chirurgische therapie van de urinewegen is, mede op basis van de ervaring uit de oncologische urologische chirurgie, uitgebreid. Dit element van onze vakgebied heeft zich ontwikkeld tot een aanvaardbare behandeling in termen van morbiditeit en resultaten, ook op langere termijn. Toch is de indicatiestelling bij mensen met functiestoornissen moeilijker dan bij mensen met kanker en is de technische uitvoering van de ingrepen complexer. Verdere analyse van de plaats van deze ingrepen bij mensen met ernstige functiestoornissen van de urinewegen door middel van technieken zoals 'technology assessment' zijn dan ook noodzakelijk. 
Naast de klassieke chirurgische technieken zijn een aantal specifieke technieken ontwikkeld die nu in gespecialiseerde centra hun waarde bewijzen. Een voorbeeld hiervan is de artificiële urinaire sphincter of Scott-prothese. Dit is een implanteerbaar apparaat uit silicone ter vervanging van het urethrale afsluitmechanisme zowel bij de man als bij de vrouw.

Verder zijn door het gebruik van elektrische stimulatie de therapeutische mogelijkheden significant toegenomen.

De niet-invasieve vormen van uitwendige of intravaginale electrostimulatie hebben een vaste plaats verworven bij de behandeling met name van inspanningsgebonden incontinentie (stress-incontinentie). Toch lijkt er voldoende evidentie te zijn dat ook bij de behandeling van andere vormen van functiestoornissen van de lage urinewegen niet-invasieve electrostimulatie een rol kan spelen.

Verder zijn op dit ogenblik een drietal technieken van operatieve electrostimulatie beschikbaar. Bovendien zullen deze opties in de nabije toekomst nog uitgebreid worden. Op dit ogenblik betreft het de volgende technieken:

- de intradurale stimulator van de sacrale zenuwen (Finetech-Brindley intradurale blaasstimulator): met dit geïmplanteerd systeem is het mogelijk bij mensen met een complete dwarslaesie lediging van de blaas op te wekken, het defecatieproces te stimuleren en een erectie op te wekken. Gebruik wordt gemaakt van electrische stimulatie via intraduraal ter hoogte van de sacrale zenuwen gelegen electrodes. ${ }^{\text {L39 }}$

- de extradurale stimulator van de sacrale zenuwen (Finetech-Brindley extradurale stimulator, Medtronic Interstim sacral anterior root stimulator): met deze alternatieve techniek wordt bij mensen met een complete dwarslaesie stimulatie nagestreefd ter hoogte van het extradurale traject van de sacrale zenuwen. ${ }^{140}$ De hoop bestaat dat met een verbeterde stimulatietechniek ook selectieve stimulatie van de blaas mogelijk is. ${ }^{\text {L1 }}$ Hierdoor zou deze techniek ook bij mensen met een incomplete laesie toegepast kunnen worden.

- de foramen stimulator (Medtronic Interstim stimulator): dit is een implanteerbaar systeem waarbij de sacrale zenuwen electrisch gestimuleerd worden met controle over de functie van de lage urinewegen tot gevolg (neuromodulatie). Deze methode kan toegepast worden zowel bij vullings- als bij ledigingsstoornissen van de blaas. 
De gunstige ervaringen met de electrisch gestimuleerde gracilisplastiek voor fecaal incontinentie hebben bovendien de mogelijkheid geopend tot toepassing van deze techniek ter hoogte van de lage urinewegen. Met name bij de behandeling van ernstige incontinentieproblematiek opent deze techniek nieuwe perspectieven. Een internationaal klinisch onderzoek naar deze methode is recent vanuit Maastricht opgestart.

Deze, weliswaar gesofisticeerde, technieken combineren zeer goede medische resultaten met een gunstig effect op de kwaliteit van leven. ${ }^{\mathbf{1 4 2}}$ Daarom is de verdere toepassing en ontwikkeling van deze vormen van therapie een essentieel onderdeel van de Neuro-Urologie. 


\section{Aandachtsgebieden van de Neuro-Urologie}

\section{Patiëntenzorg}

Eén van de hoofdtaken binnen Neuro-Urologie is het bieden van kwalitatief goede neuro-urologische zorg zowel qua diagnostiek als therapie. Op beide gebieden is expertise noodzakelijk.

Wat betreft de diagnostiek bestaat behoefte aan gespecialiseerde onderzoeksmethoden die toelaten de oorzaken van de verschillende afwijkingen in kaart te brengen. Dit is de basis voor de causale en dus de meest effectieve behandeling van functiestoornissen van de urinewegen. Het verrichten van allerlei onderzoek alleen is echter niet genoeg!

De verkregen gegevens moeten in een globaal perspectief geplaatst worden. Dit vereist van de neuro-uroloog ervaring samen met inlevingsvermogen in de leefwereld van deze patiënten.

Wat betreft de therapie ligt het accent bij de verschillende vormen van behandeling, van heel eenvoudig tot zeer ingewikkeld. Belangrijk hierbij is dat zowel patiënten als hun initiële behandelaars op de hoogte zijn van de moderne behandelingsmogelijkheden. Veel aandacht moet dus gaan naar het verstrekken van informatie. Dit laat toe die patiënten te recruteren die behoefte hebben aan neuro-urologische expertise. Zo alleen kan bekomen worden dat mensen met neuro-urologische problemen de meest adequate conservatieve dan wel chirurgische behandeling ontvangen.

Het is evident dat de verdere ontwikkeling van nieuwe technieken zoals de neurostimulatie en neuromodulatie tot de prioriteiten van de NeuroUrologie behoren. Tegelijkertijd bestaat echter de noodzaak tot verdere verfijning van de reconstructieve urologie. Zoals reeds eerder vermeld is het bij mensen met neuro-urologische problemen vaak moeilijk om hen te helpen de juiste keuze te maken uit de verschillende behandelingsopties. Hierbij moet met name gedacht worden aan de toepassing van reconstructieve technieken en nieuwe vormen van blaasvervanging en urinederivaties omwille van niet-oncologische problematiek (congenitaal, iatrogeen, post-radiotherapie, interstitiële cystitis). De uitvoering van deze ingrepen stelt hoge eisen aan de operateur teneinde aanvaardbare resultaten te bekomen. Concentratie van dergelijke ingrepen in centra met expertise verdient aanbeveling om een constante kwaliteit van zorg te garanderen. 
Gezien de combinatie van afwijkingen in het functioneren van de urinewegen met problemen ter hoogte van de inwendige genitalia van de vrouw of de werking van het anorectale kanaal is er, naast expertise op het gebied van de urologische problematiek, ook behoefte aan deskundigheid op het gebied van de Gynaecologische Urologie (of de UroGynaecologie) en de Colorectale Chirurgie. Hierbij moet ondermeer gedacht worden aan de soms complexe combinaties van gynaecologische problemen zoals prolaps met incontinentie voor urine dan wel faeces en mictieproblematiek. Het is evident dat kundigheid in deze materie specialisme overstijgende samenwerking veronderstelt. Dit kan gebeuren in het kader van een referentiecentrum waar alle mogelijkheden van diagnostiek en therapie voorhanden zijn. In het verlengde hiervan is expertise nodig voor het onderzoek van zeldzame afwijkingen en de chirurgische behandeling ervan.

De Neuro-Urologie maakt echter integraal deel uit van de Urologie. Gezien de overlap en de raakpunten tussen de neuro-urologische en de algemene urologische activiteiten is een optimale samenwerking binnen het vakgebied van de Urologie noodzakelijk. Dit bevordert de verdere ontwikkeling van de Urologie én de Neuro-Urologie. Deze samenwerking betreft zowel de verschillende subspecialistisch actieve urologen binnen academische centra onderling als de subspecialisten met de algemene urologen. Exclusiviteit dringt zich wel op bij de toepassing van specifieke neuro-urologische technieken. Deze ingrepen worden bij voorkeur gereserveerd voor een beperkt antal centra.

Op basis van deze prioriteiten is samenwerking met andere afdelingen en vakgroepen evident. Dit betreft enerzijds de diagnostiek ondersteunende afdelingen zoals de afdelingen Radiodiagnostiek en Medische Beeldvorming, Neurofysiologie, Nucleaire Geneeskunde en Medische Microbiologie en anderzijds de afdelingen Chirurgie, Neurologie, Neurochirurgie, Gynaecologie, Nefrologie, Gastro-enterologie, Fysische Geneeskunde en Revalidatie. Binnen de muren van het academisch ziekenhuis Maastricht zijn reeds formeel dan wel informeel samenwerkingsverbanden opgezet op het gebied van de patiëntenzorg. Gezamenlijk klinisch en wetenschappelijk onderzoek zal hiervan het gevolg zijn.

In verband met het structureel opzetten van een degelijke en efficiënte samenwerking kan aan het organiseren van multidisciplinaire spreekuren gedacht worden samen met de afdelingen Neurologie, Gynaecologie en 
Colo-rectale Chirurgie. Deze zouden zich vooral richten tot patiënten met neuro-urologische, uro-gynaecologische en uro-chirurgische pathologie.

De verdere ontwikkeling van klinische activiteiten binnen de NeuroUrologie leidt tot het recruteren van specifieke patiëntengroepen. De reeds goed gestructureerde regionale en supraregionale verwijzingspatronen zijn hierbij zeer belangrijk. Contacten met de ziektekostenverzekeraars binnen de Euregio moeten ook samenwerking met de omgevende landen mogelijk maken. Met België met name met Vlaanderen bestaat reeds grensoverschrijdend overleg o.a. op het gebied van de dwarslaesieproblematiek. Uitbouw van verwijzingen bij specifieke neuro-urologische problematiek vanuit deze regio maar ook de andere regio's is dan ook logisch.

\section{Onderzoek}

Het klinisch wetenschappelijk onderzoek richt zich in eerste instantie op de verdere evaluatie van de technieken die in de kliniek toegepast worden. Een hoofdaccent ligt hierbij op de 'predictieve factoren'. Hiermede wordt getracht voorspellingen te doen over de diagnostische en therapeutische waarde van de gebruikte methodes. Eerder werk heeft ons overtuigd van het belang van dergelijk predictieve factoren bij het selecteren van patiënten voor nieuwe vormen van behandeling. ${ }^{137}$ Samen met het fundamenteel onderzoek en het opzetten van een simulatiemodel van de lage urinewegen, moet dit toelaten de verdere analyse van nieuwe technieken te verfijnen.

Op het gebied van de neurostimulatie wordt aandacht geschonken aan de evaluatie van de klinische resultaten, met name op de lange termijn. Follow-up van de reeds, volgens de zogenaamde Brindley techniek, geopereerde patiënten is noodzakelijk en zal waardevolle gegevens opleveren. In het verlengde van het experimentele werk naar nieuwe vormen van electrostimulatie van de blaas, wordt gewerkt aan uitbreiding van de indicaties voor implantatie van een blaasstimulator. Deze nieuwe technieken zullen getoetst worden via klinisch experimentele toepassing en evaluatie van de resultaten. Tevens bieden deze technieken de mogelijkheid om nieuwe subsidiekanalen aan te boren.

De ontwikkeling van gezamenlijke klinische activiteiten met andere afdelingen zal het mogelijk maken gericht evaluatie-onderzoek op te zetten. Daarnaast zal aandacht geschonken worden aan het opzetten van 
epidemiologisch onderzoek op het gebied van de neuro-urologische problematiek in brede zin. Dit zal gebeuren in samenwerking met de Stichting Incontinentie Nederland (nu Stichting ISIS) en specifieke onderzoeksfondsen en patiëntenorganisaties (Preventiefonds, MS Research Stichting, Vrienden MS Research, Diabetes Fonds).

Gezien de in Maastricht reeds aanwezige expertise op het gebied van de urodynamica is het verder uitdiepen van onderzoek naar de plaats van deze technieken in de Neuro-Urologie een logische consequentie. Verder zal in her kader van de reeds bestaande ervaring mer incontinentieproblematiek de evaluatie van behandeltechnieken zoals niet-instrumentele en instrumentele bekkenbodemreëducatie aandacht krijgen.

Naast het klinisch wetenschappelijk onderzoek is het verder ontwikkelen van bestaand fundamenteel onderzoek en het opzetten van nieuwe onderzoekslijnen een belangrijk onderdeel van het takenpakket binnen de Neuro-Urologie.

Het bestaande onderzoek naar de neurofysiologie van de lage urinewegen in samenwerking met de vakgroepen neurofysiologie en anatomie moet niet alleen verdergezet worden, maar kan door nieuwe input ook vanuit de kliniek verdiept en verbreed worden. Dit zal leiden tot een beter inzicht in het systeem van neuronale netwerken. Dit moet op zijn beurt toelaten om de reeds opgezette onderzoekslijn naar modellering van de besturing van de lage urinewegen te perfectioneren. Een dergelijk model moet vervolgens toelaten om in de kliniek toegepaste technieken zoals de neuromodulatie en neurostimulatie te analyseren.

Het fundamenteel en klinisch onderzoek naar het ontwikkelen van een methode om het electromyografisch (EMG) signaal van de detrusor te meten is reeds ver gevorderd en heeft reeds tot enkele internationale publicaties aanleiding gegeven. ${ }^{\mathrm{L} 33,144}$ Dit onderzoek is ingebed in de Divisie III van het Instituut Hersenen \& Gedrag van de Faculteit der Geneeskunde. Verderzetten en uitbreiden van dit onderzoek moet leiden tot het ontrafelen van de werkingsmechanismen van bepaalde behandelingen zoals de neuromodulatie. Uiteindelijk moet dit ook een beter inzicht verschaffen in de pathologie van bepaalde functiestoornissen van de lage urinewegen. Een merkwaardig toeval is dat een eerdere onderzoekslijn, waarbij we in Nijmegen betrokken waren, ook het electrofysiologisch gedrag van de detrusor bestudeerde. ${ }^{\mathrm{L} 45}$ 
Nieuw op te zetten onderzoek situeert zich op het vlak van de farmacologische research. Dergelijk onderzoek zal in nauwe samenwerking mer de afdelingen Farmacologie en Biochemie gebeuren. Ook vanuit de farmaceutische industrie bestaat grote interesse om dergelijke projecten mede te ondersteunen. Het betreft hierbij onderzoek naar de rol van neuroreceptoren bij het ontstaan en voorkomen van functiestoornissen van de urinewegen. Dergelijk onderzoek is essentieel om een beter inzicht te verkrijgen in de pathophysiologie van de urinewegen en biedt mogelijk voldoende informatie om nieuwe behandelingen te ontwikkelen.

Het experimenteel onderzoek naar nieuwe vormen van neuromodulatie en neurostimulatie maakt verder dierexperimenteel onderzoek noodzakelijk. De tot op heden verkregen klinische resultaten vormen hierbij een enorme stimulans om hiermee door te gaan. ${ }^{\mathrm{L} 6}$

\section{Onderwijs}

Het is evident dat de verdere ontwikkeling van de Neuro-Urologie ook een positieve weerslag zal hebben op de onderwijsactiviteiten. Zowel het onderwijs aan studenten als aan assistenten-in-opleiding of niet-inopleiding zal profiteren van de hogergenoemde neuro-urologische activiteiten.

Tevens zullen een aantal post-graduaat programma's op het gebied van de Neuro-Urologie opgestart dan wel uitgebreid worden.

Gezien het belang van de neuro-urologische pathologie in de huisartsprakrijk ligt daar een belangrijke taak. Deze activiteiten zullen uiteraard geïncorporeerd worden in de reeds bestaande post-graduaat structuren. Hetzelfde geldt ook voor de post-graduaatactiviteiten voor collega specialisten zowel urologen als niet-urologen en paramedische doelgroepen. Het is duidelijk dat hierbij zowel een nationale als een internationale taakstelling wordt nagestreefd. 


\section{Plaats van de Neuro-Urologie}

\section{Neuro-Urologie in internationaal perspectief}

De Neuro-Urologie is binnen de Urologie één van de jongste subspecialiteiten. De ontwikkeling van deze subspecialiteit is ontstaan uit het besef van het enorme medische en sociale belang van de neuro-urologische parhologie. De groei van de Neuro-Urologie werd tevens gestimuleerd door de indrukwekkende toename van de diagnostische en therapeutische mogelijkheden.

Internationaal is de Neuro-Urologie een erkende subspecialiteit met een eigen tijdschrift (Neuro-Urology and Urodynamics) en een eigen vereniging (International Continence Society). In de Verenigde Staten hebben de meeste grote universiteitsklinieken binnen de afdeling Urologie een afzonderlijke eenheid voor Neuro-Urologie en Urodynamica. Naast de specifieke zorg om het neurogeen blaaslijden wordt in deze eenheden aandacht besteed aan de brede waaier van functiestoornissen van de urinewegen.

Deze eenheden zijn vaak geaffilieerd met een 'Spinal Cord Injury Center' (meestal in een ziekenhuis van de 'Veterans Administration'). Afhankelijk van de lokale organisatie is er soms ook een functioneel verband met een 'Unit for Functional Restoration'. Vanuit deze eenheden wordt de zorg voor andere neuro-urologische pathologie, bijvoorbeeld bij spina bifida, gecoördineerd.

Ook in Europa is binnen enkele grote urologische afdelingen een eenheid voor Neuro-Urologie opgericht meestal in nauwe samenwerking met de dwarslaesie-afdeling van een revalidatiecentrum. Met name in Duitsland en Frankrijk is deze samenwerking goed georganiseerd. Omwille van de concentratie van de neuro-urologische pathologie naar deze centra ontstaat vaak een zelfstandige eenheid onder de leiding van een neuro-uroloog. Vanuit deze centra wordt het beleid rondom functiestoornissen gestuurd en begeleid. In Australië zijn alle diagnostische en therapeutische mogelijkheden voorhanden in de meestal vrij grote revalidatiecentra met een dwarslaesie-afdeling.

Gezien het belang van de neuro-urologische pathologie is in enkele centra in Amerika en Europa de uroloog, verantwoordelijk voor de Neuro-Urologie, ook het hoofd of de verantwoordelijke voor het Spinal Cord Injury Center of Center for Functional Revalidation en coördineert 
de globale zorg en revalidatie van mensen met een dwarslaesie en eventueel andere neuro-urologische pathologie.

\section{Neuro-Urologie in Nederland}

De Neuro-urologie is als subspecialisme in Nederland nog weinig ontwikkeld. Toch werden de laatste jaren een aantal initiatieven genomen die de toenemende interesse voor de neuro-urologische problematiek illustreren. Op verzoek van het Centraal BeleidsOrgaan voor de Intercollegiale Toetsing (CBO) werd in 1993 een rapport uitgebracht "Het beleid bij het neurogeen blaaslijden". Sedert 1990 werden namens de Ziekenfondsraad twee ontwikkelingsgeneeskundige projecten op het gebied van de Neuro-Urologie uitgevoerd. Mede als gevolg hiervan is er ook in Nederland een bredere interesse ontstaan voor de neuro-urologische pathologie.

Er functioneert echter op dit ogenblik in Nederland geen specifiek Centrum voor Neuro-Urologie. Wel is er specifieke interesse en expertise aanwezig in enkele ziekenhuizen. Verder is aan elk van de officieel erkende revalidatiecentra met een dwarslaesie-afdeling een urologische consulent verbonden, meestal vanuit een academisch ziekenhuis. De specifieke urologische diagnostiek en therapie gebeurt dan ook buiten het revalidatiecentrum.

Naast de specialistische urologische zorg die geboden wordt in de universitaire ziekenhuizen, bestaan wel een aantal afzonderlijke centra voor de verzorging van specifieke patiëntengroepen zoals Multiple Sclerose en Spina Bifida. De kwaliteit van de neuro-urologische verzorging is echter sterk afhankelijk van de lokale organisatie en de beschikbare mensen en middelen. Er is op dit ogenblik geen duidelijke globale structuur waarbinnen deze zorg georganiseerd is. Noch op niveau van onze beroepsgroep (Nederlandse Vereniging voor Urologie), noch op niveau van de overheid zijn op dit ogenblik initiatieven genomen om hierin verandering te brengen. Wel werd in 1993 op verzoek van de Nederlandse Vereniging voor Urologie de Werkgroep Neuro-Urologie en Urodynamica opgericht met het doel het onderzoek op het gebied van de NeuroUrologie en de Urodynamica te stimuleren en de neuro-urologische zorg te optimaliseren.

Sedert 1982 tracht de Stichting Incontinentie Nederland, recent omgedoopt tot Stichting ISIS, de belangen van mensen met continentiepro- 
blemen te behartigen en wetenschappelijk onderzoek op dit gebied op te zetten. Door de nog steeds aanwezige taboesfeer rondom incontinentie is het echter voor deze Stichting moeilijk voldoende donateurs te werven om vanuit een onafhankelijke positie deze initiatieven te nemen.

Vanaf het begin van de academisering van de afdeling Urologie van het academisch ziekenhuis Maastricht in 1987 werden de functiestoornissen van de urinewegen als prioriteit geoormerkt zowel op het gebied van de patiëntenzorg als van het onderzoek. Door het enthousiasme en de inzet van Prof. Janknegt, de eerste hoogleraar in de Urologie aan de toenmalige Rijksuniversiteit Limburg, werd een bloeiende afdeling Urologie met academische uitstraling ontwikkeld. De eerste leerstoel in de NeuroUrologie is daarvan het resultaat. De afdeling Urologie van het azM vervult dan ook een voortrekkersrol in de neuro-urologische patiëntenzorg.

Voortzetting en uitdieping van deze activiteiten is nu aan de orde. Het ordinariaat in de Neuro-Urologie opent bovendien de mogelijkheid tot verdere uitbreiding van de neurowetenschappen binnen de UM en het azM. Deze aanstelling creëert de mogelijkheid tot ontwikkeling van een aantal geheel nieuwe en belangrijke onderzoeks- en behandellijnen.

Binnen de Faculteit der Geneeskunde van de Universiteit Maastricht is het zwaartepuntsthema Gedrags- en Hersenstoornissen (G\&H) ontwikkeld, waarin ook de vakgroep Urologie een plaats heeft. Inmiddels is dit zwaartepunt door de Universiteitsraad en het College van Bestuur officieel erkend als Instituut Hersenen \& Gedrag. In het kader van dit Instituut wordt gewerkt aan de verdere inbedding en ontwikkeling van het klinische maar zeker ook het fundamentele onderzoek op het gebied van de Neuro-Urologie. 


\section{Samenwerking}

Op basis van een analyse van de situatie in de omringende landen en wereldwijd in landen met vergelijkbare medische infrastructuur als Nederland, is het duidelijk dat specifieke neuro-urologische expertise nodig is. Deze behoefte wordt ook aangegeven binnen de beroepsgroepen die met de verzorging en behandeling van mensen met neurourologische pathologie betrokken zijn. Ook door verschillende patiëntenverenigingen is aandacht gevraagd voor de neuro-urologische problematiek.

Adequate neuro-urologische zorg kan uiteraard vanuit het azM georganiseerd en gecoördineerd worden zonder te raken aan de zelfstandigheid van de bestaande afdelingen en centra. De neuro-urologische activiteiten zijn goed ingebed in de structuur van het academisch ziekenhuis Maastricht en hebben een duidelijk verband met de Faculteit der Geneeskunde van de Universiteit Maastricht. Deze gespecialiseerde patiëntenzorg vereist immers een uitgebreide medische infrastructuur voor de specifieke diagnostiek en nieuwe therapeutische mogelijkheden. Het noodzakelijke pariëntgebonden en zeker het meer fundamentele onderzoek vereist een academische ondersteuning voor de verdere profilering. De aanwezige faciliteiten binnen het azM en de UM maken dit zeker mogelijk.

Ook voor opleiding en scholing zijn dwarsverbanden met een universitair ziekenhuis en een medische faculteit nodig. Contacten zijn gelegd met de basiswetenschappen binnen de Faculteit der Geneeskunde (Anatomie, Biochemie, Fysiologie, Electrofysiologie, Farmacologie). Samenwerking met andere faculteiten (Economie) en andere instituten (Biomedische technieken, TU Eindhoven) behoort tot de mogelijkheden en zal een essentieel onderdeel vormen van de verdere profilering van de Neuro-Urologie.

Samenwerking wordt nagestreefd met andere universiteiten en onderzoeksinstituten in Nederland. Het huidige beleid van de overheid, daarin gesteund door de adviezen van de Nederlandse organisatie voor Wetenschappelijk Onderzoek (NWO), noodzaakt tot verregaande samenwerking binnen onderzoeksinstituten. Dit leidt tevens tot concentratie van de beschikbare middelen. Het verwerven van middelen uit de eerste, 
tweede en derde geldstroom in het kader van het Instituut Hersenen $\&$ Gedrag behoort tot één van de prioriteiten.

Er bestaat reeds een goede samenwerking met andere centra nationaal en internationaal. Het verder uit te breiden samenwerkingsverband op klinisch gebied binnen de Euregio biedt unieke mogelijkheden voor het opzetten van gemeenschappelijke onderzoeksprojecten in het kader van de BioMed programma's van de Europese Unie (EU).

De medewerking van de afdeling Urologie aan gezamenlijke activiteiten in het kader van de internationale verenigingen met interesse in de Neuro-Urologie (International Continence Society, Urodynamics Society) wordt nog geïntensifieerd. Zelf hebben we initiatieven genomen op het gebied van de standaardisatie en de evaluatie van de neuro-urologische zorg in het kader van deze organisaties. Onze activiteiten in het kader van de overkoepelende internationale organisaties (European Association of Urology, European School of Urology, American Urological Association, Société Internationale d'Urologie) zullen eveneens hiertoe bijdragen. 


\section{Toekomstperspectieven of sterkte en problemen van de Neuro-Urologie}

Zowel in Nederland als in omringende landen is er een duidelijke vraag naar uitbreiding van de neuro-urologische zorg. Stilaan ontstaat het besef dat functiestoornissen van de urinewegen een belangrijk medisch en maatschappelijk probleem zijn, mede door de vergrijzing van de bevolking. De kosten als gevolg van de verzorging (care) van mensen met deze problemen zijn de laatste jaren zodanig toegenomen dat de instanties die het geld van de gezondheidszorg beheren en verdelen nu ook geïnteresseerd zijn in het behandelen (cure) van deze problematiek. Op basis hiervan is in 1996, op initiatief van de Commissie Ontwikkelingsgeneeskunde van de Ziekenfondsraad, een 'Cure or care' project gestart in de regio Zuid-Limburg. In dit project wordt bestudeerd in welke mate de incontinentieproblematiek in verpleeg- en bejaardenhuizen door gerichte therapie verholpen kan worden eerder dan uitsluitend verzorgd. De uitwerking van dit project werd toevertrouwd aan de afdeling Urologie van het azM.

Dit toont nogmaals aan dat de kwalitatief hoogstaande organisatie zowel personeel als materieel en de dwarsverbanden met een volledig uitgerust academisch ziekenhuis borg staan voor een unieke positie binnen de gespecialiseerde gezondheidszorg in Nederland. Een dergelijke organisatie als referentiecentrum betekent een versterking van de topklinische functies voor het azM en de facultaire zwaartepunten van de UM.

Het huidige budgetsysteem dat binnen de gezondheidszorg in Nederland op dit ogenblik gehanteerd wordt, is echter niet bevorderlijk voor de verdere ontwikkeling van jonge subspecialismen. Bij het toepassen van de neuro-urologische zorg wordt frequent gebruik gemaakt van prothese materiaal of instrumenten voor éénmalig gebruik (devices) met een hoge aanschafprijs. De kosten hiervan wegen zeer zwaar op het ziekenhuisbudget, de baten echter worden meestal buiten het ziekenhuis geboekt. Zeker wanneer alleen maar naar de korte termijn effecten gekeken wordt, is neuro-urologische zorg relatief duur. De kosten-baten analyse wordt meestal slechts positief met wat langere follow-up. De meeste projecten laten echter een dergelijke lange-termijn-evaluatie niet toe. We zijn dan ook voorstander van het vaker toepassen van moderne technie- 
ken van technology assessment bij de evaluatie van nieuwe diagnostische methodes en behandelopties. Hierbij moet echter ook aandacht geschonken worden aan een kritische analyse van de zogenaamde 'klassieke technieken'. Deze worden algemeen als gouden standaard gehanteerd zonder dat ooit een adequaat onderzoek naar hun 'verdiensten' verricht is.

Bovendien is er een discrepantie tussen het uitgebreide onderzoek in verschillende fases waaraan nieuwe farmaceutische middelen onderworpen worden vooraleer commercialisering mogelijk is en het quasi automatisch ter beschikking komen van technische hulpmiddelen gebruikt in de patiëntenzorg. Eénmaal het europese keurmerk van veiligheid van het materiaal (CE-mark) afgeleverd is, kunnen deze produkten immers in Europa verkocht worden zonder verder analyse naar hun effectiviteit en veiligheid bij de behandeling van patiënten.

Bij de beoordeling van deze nieuwe technieken mag echter, gezien de aard van de neuro-urologische problematiek, niet alleen gekeken worden naar de verhouding tussen kosten en baten in louter financiële termen. Een nauwkeurige analyse van de kwaliteit-van-leven aspecten is essentieel. De vraag stelt zich: welke prijs is de maatschappij bereid te betalen voor het verbeteren van de levensomstandigheden van een bepaalde categorie van patiënten? Het gevaar van kosten-baten analyses is immers dat uitsluitend gekeken worden naar de financiële winst voor de verzekeraar en de overheid en dat andere aspecten verwaarloosd worden. De problemen rond het organiseren van de financiële middelen wordt nog al te vaak op de schouders van de behandelaars gelegd. De gevolgen hiervan zijn meestal voelbaar in de spreekkamer. Daar wordt de arts in de rol geplaatst van boodschapper van slecht nieuws. Frustrerend hierbij is dat de verantwoordelijken van de ziektekostenverzekeringen zich vaak opsluiten in de ivoren torens van de macht gelokaliseerd in luxe gebouwen, de kathedralen van het 'fin du siècle'.

Ook de interesse van de overheid is vooral toegespitst op de financiële aspecten van de gezondheidszorg en minder op de gevolgen van het beleid. Toch hebben overheidsmaatregelen een belangrijke invloed op de globale kwaliteit van de zorg en zeker ook op de arts-patiënt relatie. Dit schept de paradoxale situatie dat wel de expertise en de infrastructuur voor gespecialiseerde diagnostiek en behandeling aanwezig zijn maar niet de middelen. Hierdoor kan geen optimaal gebruik gemaakt worden 
van de aanwezige mogelijkheden. Door deze situatie ontstaat bovendien het risico dat grote ongelijkheid in de toegang tot de zorg ontstaat.

Door de geografisch excentrische ligging van het azM kunnen zich logistieke problemen voordoen bij de verdere ontwikkeling van een expertise centrum met name wat betreft de patiëntenzorg. Overleg met de ziektekostenverzekeraars en de particuliere verzekeraars moet deze obstakels kunnen wegnemen. Een interessant initiatief werd recent genomen met het ter beschikking stellen van hotelfaciliteit in de nabijheid van het academisch ziekenhuis. Hopelijk kan mede door dit soort initiatieven de afdeling Urologie van het azM haar supraregionale taak wat betreft de neuro-urologische zorg verder uitbouwen. Verondersteld mag worden dat het reeds aanwezige verwijzingspatroon van binnen en buiten Nederland gecontinueerd zal worden.

Nog steeds is er een ongelijke verdeling van de middelen uit de eerste, tweede en derde geldstroom voor wetenschappelijk onderzoek ten nadele van de Neuro-Urologie. De farmaceutische industrie en de producenten van instrumentarium en prothesen leggen echter al veel langer een grote aandacht aan de dag voor de neuro-urologische pathologie. Veel vooruitgang in onze kennis op het gebied van functiestoornissen van de urinewegen is dan ook aan hun te danken. Toch houdt deze situatie een risico in. Sterk op de praktijk gericht onderzoek dreigt voorrang te krijgen op fundamenteel onderzoek. Toch is dit laatste een primaire taak van ieder academisch onderzoeksinstituut. Daarom leidt de toenemende aandacht voor de klinische problematiek hopelijk ook tot een groeiende interesse vanuit die organisaties die het wetenschappelijk onderzoek in Nederland financieel ondersteunen. Dit zou uiteindelijk moeten leiden tot het gemakkelijker toekennen van onderzoeksgelden voor fundamenteel onderzoek op het gebied van de Neuro-Urologie.

Ook het onderwijs in de Neuro-Urologie is wat stiefmoederlijk bedeeld. Het maastrichtse probleemgestuurde onderwijs biedt weliswaar mogelijkheden om hierin verandering te brengen maar vormt in Nederland een uitzondering. Ook in de klassieke handboeken worden functiestoornissen van de urinewegen zeer beperkt besproken. De veranderende opzet van het medisch onderwijs in Nederland biedt echter mogelijkheden om in deze situatie verbetering te brengen. 


\section{Het ordinariaat in Urologie in het bijzonder de Neuro-Urologie aan de Universiteit Maastricht}

Zowel in Nederland als in omringende landen is er interesse in de Neuro-Urologie. Gezien het belang van de Neuro-Urologie als onderdeel van de Urologie en tevens als behandelings- en onderzoekszwaartepunt binnen de afdeling/vakgroep Urologie van het academisch ziekenhuis Maastricht en de Universiteit Maastricht, is het belangrijk deze betrokkenheid te intensiveren. Bovendien moeten de onderzoeks- en behandelactiviteiten gewaarborgd worden en zo nodig uitgebreid.

Het ogenblik is dus gunstig voor het oprichten van een leerstoel in de Neuro-Urologie en de daarmede verbonden wetenschappelijke, klinische en didactische mogelijkheden. Toch was het instellen van deze leerstoel niet evident. De te beperkte middelen van de medische faculteiten en academische ziekenhuizen en het blokkeren van het uitbreiden van medisch specialistische zorg maken het in de huidige context moeilijk om bijzondere leerstoelen op een onderdeel van een vakgebied op te richten. Dat dit in Maastricht toch lukte, is te danken an het doorzettingsvermogen van Professor Janknegt en van allen in het ziekenhuis en de faculteit die betrokken waren bij de oprichting van deze leerstoel. Ook de inzet van de Stichting Neuro-Urologie namens de Stichting Incontinentie Nederland (nu Stichting ISIS) was belangrijk. Financiële ondersteuning werd geleverd vanuit de medische industrie. Zonder deze subsidie was deze leerstoel niet mogelijk geweest. Toch betekent dit feit wel een potentiële bedreiging voor de zelfstandigheid van de ordinarius. De belangrijke financiële bijdrage vanuit het academisch ziekenhuis Maastricht staat echter borg voor een goede verankering in de basisstructuren van ziekenhuis en faculteit.

Het ordinariaat in de Neuro-Urologie opent de mogelijkheid tot verdere uitbreiding van de neurowetenschappen binnen de UM. De erkenning van het Instituut Hersenen \& Gedrag door de Universiteitsraad en het College van Bestuur biedt hiervoor een goede basis. Het instellen van de leerstoel in de Neuro-Urologie creëert de mogelijkheid tot ontwikkeling van nieuwe onderzoekslijnen. 
De afdeling Urologie van het azM heeft zich nationaal en internationaal vooral geprofileerd binnen de Neuro-Urologie. Voortzetting van dit klinisch zwaartepunt en uirdieping van de activiteiten op dit gebied is logisch. De bestaande samenwerking met de economische afdelingen en instituten garandeert bovendien een verdieping van de kennis betreffende de vergelijking tussen conventionele behandelingstechnieken en nieuwere methodes.

Samenwerking op het gebied van de Neuro-Urologie binnen Nederland maar ook met de omringende landen in het kader van Euregio biedt unieke kansen. De prille samenwerking met de afdelingen Urologie van universiteitsklinieken van Aken en Luik is hiertoe een eerste aanzet. Zeker mede door de goede persoonlijke contacten met de hoofden en de staven van deze afdelingen zal dit uitgroeien tot een voor West-Europa uniek samenwerkingsverband.

Het instellen van een ordinariaat betekent echter ook de invulling hiervan door een functionaris. Waarom zou iemand een dergelijke positie ambiëren?

De hogergenoemde eisen van patiëntenzorg, onderzoek, onderwijs en organisatie maken dat de invulling van dit ordinariaat een "uitdaging" kan genoemd worden.

Kwalitatief goede neuro-urologische zorg vereist reflectie. Ik bedoel hiermede de tijd en de ruimte voor innerlijke rust en kalmte en de mogelijkheid tot het ontwikkelen van "Het innerlijk behang". ${ }^{\mathrm{N} 7}$ Bovendien moet het beleid gestuurd worden door 'Prudentia'N8 of vooruitziendheid. I $\mathrm{k}$ heb alvast in mijn kamer in het ziekenhuis een ets opgehangen van Hiëronymus Cock, naar een tekening van Pieter Breughel de oudere. ${ }^{\text {N9 }}$ Het thema van deze prent is de "Prudentia". Onderaan staat als bijschrift de tekst "Si prudens esse cupis, in futurum prospectum ostende, et quae possunt contingere, animo tuo cuncta propone". Op deze prent wordt links onderaan een patiënt op zijn ziekbed afgebeeld met aan één kant een geestelijke met de Bijbel en aan de andere kant een dokter met de matula. ${ }^{\mathrm{N} 10}$ Dit beeld staat symbool voor de situatie waarin zich iedere arts bevindt wanneer hij samen met een patiënt belangrijke beslissingen moet nemen. De prudentia is derhalve een opdracht voor iedere arts en zeker voor de neuro-uroloog. 
Toch mag deze houding er niet toe leiden patiënten tor alleen maar cliënten te degraderen. Patiënten zijn geen cliënten. Niet het commerciële wel het menselijke aspect moet overwegen. Dit is veel meer dan commercie of handel. Goede patiëntenzorg is wel ónderhandelen, wikken en wegen met uitsluitend de bedoeling dat de pariënt winst boekt.

Veel mensen met functiestoornissen van de urinewegen willen overigens liever niet als 'patiënt' bestempeld worden maar wel als 'mensen met een functiestoornis'.

Ze hebben gelijk.

Volgens de eerste definitie betekent patiënt "lijder van een ziekte" en de meeste mensen met functiestoornissen van de urinewegen lijden immers niet aan een ziekte. Ook de tweede definitie van het woord patiënt namelijk "iemand die iets onaangenaams moet ondergaan" is hopelijk niet al te vaak van toepassing!

Daarom is het belangrijk deze mensen in hun totaliteit te benaderen en niet alleen aandacht te hebben voor hun afwijkend orgaan. Professor Moonen, één van mijn opleiders en een pionier op het gebied van de functiestoornissen van de lage urinewegen, vatte dit samen in de titel van zijn afscheidscollege: "Ne umquam pars pro toto".

Ik ben er van overtuigd dat in het academisch ziekenhuis Maastricht en de faculteit der Geneeskunde van de Universiteit Maastricht de omstandigheden aanwezig zijn om de hogergenoemde taken naar behoren te kunnen vervullen. Toch wil ik hier stellen dat een goed team beter is dan éen krachtig persoon. De opdracht is immers niet gering. Ik wil echter deze uirdaging aangaan. Mijn gezin en de kunst, als drager van ons heimwee naar het volmaakte, zullen mij daar helpen. ${ }^{\mathrm{N}}$.

Waarom werd deze leerstoel aan een vlaming toegekend?

$\mathrm{U}$ schrikt misschien van deze vraag. Toch werd ze in de periode van mijn aanstelling gesteld, weliswaar door mensen van buiten de Universiteit Maastricht.

In een Europa dat stilaan overgaat naar de 21 e eeuw kan deze vraag eenvoudig beantwoord worden mer een gezegde uit de 16e eeuw en wel van Marnix van Sint Aldegonde: wij zijn twee ranken aan één stam. ${ }^{\mathrm{N} 12}$ Indien dit de vraag onvoldoende beantwoordt, zou ik kunnen aangeven dat ik zal trachten de lijfspreuk van de bourgondische hertogen van Vlaanderen "Plus est en vous" re combineren met deze van Willem van Oranje "Point n'est besoin d'espérer pour entreprendre, ni de réussir pour persévérer". 


\section{Dankwoord}

Zeer gewaardeerde toehoorders,

Nu ik bijna aan het einde van deze rede ben gekomen ben, sluit ik deze gaarne af met een dankwoord.

Mijnheer de Rector Magnificus, Leden van het College van Bestuur van de Universiteit Maastricht, Leden van het College van Decanen, Leden van de Raad van de Faculteit der Geneeskunde, Leden van de Raad van Bestuur van de academisch ziekenhuis Maastricht, Leden van de Commissie van Deskundigen, Leden van het College van Toezicht, Leden van het Bestuur van de Stichting Sint Annadal, Leden van het Bestuur van de Stichting Neuro-Urologie ten behoeve van de Stichting Incontinentie Nederland (nu Stichting ISIS),

ik dank $U$ voor het vertrouwen dat $U$ mij hebt geschonken door mij op deze leerstoel Neuro-Urologie te benoemen. Met het instellen van deze leerstoel heeft $U$ een primeur gerealiseerd in Nederland en wellicht ook in Europa. Ik zal deze uirdaging met al mijn energie aangaan.

Hooggeleerde Janknegt, beste Ruud,

Ik dank je voor de kans die jij me hebt geboden om aan deze positie invulling te geven. Dat ik samen met mijn gezin hiervoor naar Maastricht moest afzakken heb je samen met Inge door grote gastvrijheid opgevangen. Onze welgemeende dank gaat vandaag bijzonder naar jullie twee.

Collegae hoogleraren van de zusterfaculteiten in Nederland, $U$ heeft ingestemd met mijn benoeming. Ik dank $U$ hiervoor. Tevens wil ik $U$ bedanken voor de prettige samenwerking die de voorbije jaren reeds tot stand is gekomen. We zullen deze verderzetten.

Collegae hoogleraren uit het buitenland, $U_{w}$ aanwezigheid vandaag ondersteunt het idee van samenwerking over de landsgrenzen heen. Ik ben hier heel blij om en dank $U$. 
Leden van de staf van de afdeling Urologie van het academisch ziekenhuis Maastricht,

U heeft mij zeer gastvrij ontvangen alhoewel de komst van een 'vreemde' niet evident was. Ik hoop dat we in een goede verstandhouding samen kunnen werken aan wat we in deze rede aangegeven hebben.

Dames en Heren overige medewerkers van de afdeling Urologie, Vanaf het begin van mijn werkzaamheden in Maastricht heeft $U$ mij met enthousiasme welkom geheten. Laat ons op deze weg verdergaan.

Dames en Heren assistenten in opleiding tot uroloog,

Ik heb het voorbij jaar het voorrecht gehad met $U$ te kunnen samenwerken op het gebied van de patiëntenzorg en het initiëren van wetenschappelijk onderzoek. Het zal mij een genoegen zijn dit in de komende jaren verder te zetten.

Dames en Heren studenten,

Mijn eerste stappen binnen het maastrichtse onderwijssysteem heb ik gezet. Ik hoop dat ik mijn interesse in de geneeskunde en in het bijzonder de Urologie kan overdragen.

Zeer geleerde Baeten, beste Cor, Jouw enthousiasme voor het werk hier in Maastricht was een belangrijke stimulans om deze positie te aanvaarden. Onze paden zullen zich in de komende jaren nog vaak kruisen. Ik kijk er naar uit!

Zeer geleerde De Cannière, zeer geleerde De Backer, Hooggeleerde Coolsaer, Hooggeleerde Moonen, Hooggeleerde Debruyne,

$\mathrm{U}$ heeft mij opgeleid en gevormd. Veel dank ben ik aan $U$ verschuldigd.

Hooggeleerde Tanagho, beste Emil, Hooggeleerde Schmidt, beste Rick, $\mathrm{U}$ heeft door uw enthousiasme bij mij de interesse gewekt voor de Neuro-Urologie. Ik ben $U$ hiervoor dankbaar.

Zeer geleerde Mattelaer, beste Johan, Hooggeleerde Van Camp, beste Koen, Hooggeleerde Hommes, beste Otto, huidige en vroegere leden en medewerkers van de staf van de afdeling Urologie van het Academisch Ziekenhuis Nijmegen St Radboud, 
We hebben in het verleden prettig samengewerkt. Op deze dag en vanaf deze plaats wil ik U hiervoor bedanken.

Leden van het bestuur van de Stichting Vrienden MS Research, Leden van het Bestuur van de Nierstichting, Leden van het Bestuur van het Diabetes Fonds, Leden van de Nationale Commissie Chronische Zieken, Leden van de Commissie Ontwikkelingsgeneeskunde van de Ziekenfondsraad, Bestuur van het MARCH programma van het BioMed II programma van de Europese Unie,

Door uw ondersteuning voor wetenschappelijke projecten heeft $U$ mede mijn loopbaan mogelijk gemaakt. Hiervoor mijn dank.

Ook wil ik de verantwoordelijken van de volgende bedrijven bedanken die door hun financiële steun het instellen van deze leerstoel mede mogelijk gemaakt hebben: Medtronic Interstim, Lorex Synthélabo, Bayer, Hoechst Marion Roussel, Coloplast, Pharmacia \& Upjohn, Pie Medical, Byk Nederland, Ferring.

Mijn in 1980 overleden vader wil ik bedanken omdat hij mij inspireerde voor wetenschappelijk vorsingswerk en zo de basis legde voor mijn academische loopbaan. Zoals Jozef Deleu vond hij dat de kennis van het verleden essentieel was voor het kennen en begrijpen van het heden. ${ }^{\mathrm{N} 13}$

Mijn moeder en mijn schoonouders dank ik voor de onbaatzuchtige inzet waarop we steeds beroep mochten doen en die voor een groot deel mijn ontplooiing als uroloog mogelijk gemaakt heeft.

Een speciale plaats wil ik aan het eind van deze rede inruimen voor mijn gezin. Reeds eerder gaf ik aan dat zij het baken zullen zijn tijdens deze tocht. Zij zorgen voor de verrijking van mijn "Innerlijk behang" en behoeden mij ervoor alleen maar vakfanaat te worden. ${ }^{\text {N14 }}$

Beste Kristin,

Jouw bereidwilligheid om nogmaals te verhuizen en vele vrienden opnieuw achter te laten om deze stap van mijn loopbaan mogelijk te maken was zeer groot. Ik hoop dat mijn werkplezier en alles wat we samen nog willen ondernemen hiervoor voldoende compensatie biedt. 
Ik kan mijn gevoelens niet beter uitdrukken dan door het volgende stukje uit een sonnet van William Shakespeare ${ }^{\mathrm{N} 15}$ :
Thy love is better than high birth to me,
Richer than wealth, prouder than garments' cost,
Of more delight than hawks or horses be;
And having thee, of all men's pride I boast -

Beste Egmond, Helena, Bavo, Katarina en Teresa,

Ik wil niet teruggrijpen naar woorden zoals "jullie zijn het belangrijkste in mijn leven". Ik weet dat onze beslissing om naar Maastricht te komen ook voor jullie heel wat heeft teweeggebracht en dat in de toekomst wellicht meer mijn afwezigheid dan mijn aanwezigheid zal opvallen. Toch hoop ik dat jullie later op deze fase in ons gezinsleven kunnen terugblikken met in gedachte de zin uit de Aeneïs van Vergilius: "Haec olim meminisse iuvabit". ${ }^{16}$

Met François-Marie Arouet beter bekend als Seigneur de Voltaire zou ik nu willen zeggen "Il faut cultiver notre jardin" ${ }^{\mathrm{N} 17} \mathrm{Dit}$ is letterlijk en figuurlijk bedoeld. Letterlijk staat er ons nog veel werk te wachten in ons nieuwe huis dat een thuis moet worden voor ons allemaal. Figuurlijk staat er mij nog heel wat werk te wachten, om waar te maken wat ik in deze rede heb aangekondigd. Ik hoop op jullie steun en begrip hierbij. Een goede vriend schreef mij onlangs een brief en eindigde deze met de volgende zin: Philip, succes met je drukke leven maar denk erom "een carrière is een loopbaan en geen renbaan". Ik zal trachren mij hier in ieder geval af en toe aan te houden.

\section{Zeer geachte toehoorders,}

Nog maar net heeft de Neuro-Urologie een aparte plaats verkregen als sub-specialisme binnen de Urologie maar toch moet dit onderdeel van de Urologie een belangrijke rol gaan vervullen binnen het geheel van de urologische pathologie, diagnostiek en therapie.

Ik heb gezegd. 


\section{Noten}

Nl Guillaume Duchenne (1806-1875): Frans neuroloog met een bijzondere gave voor klinische sympromatologie. Hij was één der grondleggers van de electrotherapie en de electrodiagnostiek. Hij heeft talrijke ziektebeelden beschreven, waarvan er verscheidene naar hem zijn genoemd. Mer name de progressieve spierdystrofie, gekenmerkt door toenemende spierzwakte door verval van spiervezels is bekend als de ziekte van Duchenne.

Jean-Martin Charcot (1825-1893): Frans neuroloog en psychiater. Voor hem werd in 1882 een leerstoel voor de ziekten van het zenuwstelsel in het leven geroepen. Hij was een briljant clinicus en beschreef als eerste de typische symptomen van multiple sclerose. Ook op het gebied van de psychiarrie verrichre hij baanbrekend werk. Hij was het die Sigmund Freud de stimulans gaf tot zijn onderzoek van het onbewuste.

N2 Neuromodulatie: is een techniek waarbij gebruikt gemaakt wordt van electrische stroom aangebrache ter hoogte van zenuwbanen om functiestoornissen in het menselijk lichaam te veranderen. Door het aanbrengen van electrische impulsen ter hoogte van een sacrale zenuwwortel die aan- en afvoerende zenuwen bevat van en naar de blaas, kunnen afwijkingen in de werking van de blaas gecorrigeerd worden. Dit effect is waarschijnlijk het gevolg van veranderingen ter hoogte van het onderste gedeelte van het ruggemerg waar de coördinatic van de blaascontrole gelocaliseerd is.

N3 Priapisme: is een blijvende en pijnlijke erectie van de penis (stijfheid van het mannelijke lid). Deze kan spontaan optreden bij bepaalde aandoeningen zoals sickle cell anaemie (een erfelijke ziekte die bij de zwarte bevolking voorkomt) maar kan ook veroorzakt worden door een plorse onderbreking van het ruggemerg zoals bij het optreden van een dwarslaesie of tengevolge van een verhanging. De naam komt van de griekse god Priapus. Hij wordt afgebeeld als een kleine gebaarde man, die met twee handen zijn met enkele vruchten beladen voorschoot optilt boven een overmatig grote fallus. Het enorme geslacht van Priapus heeft hem legendarisch gemaakt. De romeinen maakten grove beeldjes van hem om boomgaarden te bewaken, met zijn enorme lid dieven en vooral dievegges afsehrikkend. Van vruchtbaarheidssymbool werd hij zo geleidelijk een obscene vogelverschrikker.

N4 Overloopincontinentie: is een vorm van incontinentie gekenmerkt door druppelgewijs urineverlies tengevolge van een overvolle blaas. Dit probleem kan optreden wanneer de blaasuitgang afgesloten is door overdruk b.v. ten gevolge van prostaatvergroting of wanneer de blaasspier verlamd is en niet meer kan samentrekken om normaal te ledigen.

N5 Efedrine: is een farmacologische stof die via stimulatie van het orthosympathische zenuwstelsel o.a. glad spierweeefsel kan doen samentrekken. Ter hoogte van de blaasuitgang en rondom de prostaac bevindt zich glad spierweefsel dat door samentrekking voor een betere afsluiting kan zorgen.

N6 Lewis cystometer: in 1927 ontwikkelde Lewis de eerste cystomanometer met anaeroïde drukmeting. Het ging om een klein en vrij goedkoop apparaat dat in talrijke klinieken aangeschaft werd. Dit toestel was zeer algemeen in gebruik tot het vervangen werd door apparaten met rechtsreekse drukregistratie.

N7 "Her innerlijk behang": is een dichtbundel van Hans Lodeizen, ook 'de dichter van de jeugd' genoemd, die in 1950 op zesentwintigjarige leeftijd overleden is. In deze bundel 
met de veelzeggende titel wordt voortdurend verwezen naar het schuiloord dat het 'innerlijk behang' van de mens vormt tegen de grauwe werkelijkheid van het dagelijks leven. Het 'innerlijk behang' is de metafoor waarbij het innerlijke leven van de mens wordt vergeleken met een kamer, behangen met ervaringen, inzichten, verlangens en herinneringen.

De kwaliteit van ons 'innerlijk behang' is dus van doorslaggevende betekenis voor de wijze waarop mensen aan het leven zelf participeren.

N8 Prudentia: is de ecrste en de belangrijkste van de 4 cardinale of niet-theologische deugden. De andere drie zijn Iustitia (de rechtvaardigheid), Fortitudo (het uithoudingsvermogen) en Temperantia (de gernatigdheid). Daarnaast zijn er de 3 theologische deugden nl. Spes (de hoop), Fides (het geloof) en Caritas (de naastenliefde).

Met Prudentia wordt niet zozeer voorzichtigheid of aandacht bedoeld maar wel vooruitziendheid in de zin van wijsheid en gezond verstand met de bedoeling een onderscheid te maken tussen goed en kwaad ten dienste van de deugd. De Prudentia wordt beschouwd als een absolute voorwaarde voor een goed leven d.w.z. een leven vol goedheid.

N9 Pieter Brueghel de Oudere (ca. 1521-1569) werkte in Antwerpen en Brussel en is vooral bekend omwille van de levendige afbeeldingen van het vlaamse volksleven. Rond 1550 reist hij naar Italië en bij zijn terugkeer in Antwerpen werkt hij samen met Hiëronymus Cock. Deze geeft een aantal etsen uit die de deugden en de ondeugden voorstellen. De etsen werden waarschijnlijk vervaardigd door Philips Gallé en zijn gebaseerd op oudere tekeningen van Brueghel. De tekening en de ets Prudentia dateren beide uit 1559 .

Onder de ets staat de tekst "Si prudens esse cupis, in futurum prospectum ostende, et quae possunt contingere, animo tuo cuncta propone", vrij vertaald "Als je vooruirziend wil zijn, denk dan steeds aan de toekomst en bereid je voor op alle mogelijke gebeurtenissen van het leven".

N10 Marula: is een glazen bolvormig recipiënt (in de vorm van de urineblaas) dat gebruikt werd om de kleur en het aspect van de urine van zieken te bestuderen. De uitdrukking "matula facit medicum" was tot eind $16^{c}$ eeuw zeer populair. De toestand van de urine werd beschouwd als representatief voor de ganse persoon en de menselijke anatomie werd belichaamd in de structuur van de fles (van de hals = de hersenen tor de bodem $=$ de nieren en de teelballen).

N1I In De Standaard van dinsdag 4 oktober 1994 verscheen een opinie-arrikel "Kunst draagt ons heimwee naar het volmaakte" van Jozef Deleu, hoofdredacteur van Ons Erfdeel, het blad van de Stichting Septentrion die de Nederlands-Franse culturele uitwisseling behartigt. Hij schrijft hierin o.a. "De troost die kunst en cultuur bieden, maakt voor velen de zwaarste beproevingen van her leven draaglijk. Muziek, beeld en woord zijn door de eeuwen heen dragers van ons heimwee naar het volmaakre.". Hij geeft verder aan dat ook de technologisch geschoolde mens weet moet hebben van de ontwikkelingen en de wisselwerking tussen de creativiteit van de kunstenaar en de uirvindingen en de toepassingen ervan in de wetenschap.

N12 Marnix, Filips heer van Sint Aldegonde (Brussel 1540-Leiden 1598) was een ZuidNederlands politicus, geleerde en letterkundige. Hij zou rond 1569 de tekst van het Wilhelmus geschreven hebben. In $1571 \mathrm{kwam}$ hij in diense van Willem van Oranje en in die hoedanigheid bewerkte hij de overgang van de Oranjes tot het calvinisme. In 1577 werd hij lid van de Raad van State en liet zich in 1583 door Oranje bewegen de 
post van buitenburgemeester van Antwerpen aan te nemen, speciaal belast met de verdediging van de stad. In deze opdracht mislukte hij en vanaf 1585 houdt hij zich uitsluitend bezig mer literaire arbeid.

N13 In zijn opinie-artikel "Kunst draagt ons heimwee naar het volmaakte" (zie NI1) schrijft Jozef Deleu: "De kennis van het verleden vormt een referentiekader waarbinnen wij onszelf en onze activiteiten kunnen duiden en begrijpen. Dank zij een uitgebreide algemene culcuur zijn wij minder manipuleerbaar en zelfstandiger in de vorming van onze mening".

N14 In hetzelfde artikel (zie N11 en N13) stelt Deleu dat de verrijking van het "Innerlijk Behang" van de mens door middel van kunst en cultuur van het grootste belang is voor het functioneren van de democratie zelf. Vakfanaten immers hebben alleen oog voor het smalle en steile pad dat hen naar 'verheven coppen' leidt. Wat hen meestal ontbreekt is het inzicht in het geheel, waardoor zij gedragen en gevoed worden. Deleu geeft echter aan dat dit specialisatie waaraan de maatschappij en de wetenschappelijke en technologische wereld zoveel behoefte heeft, niet uitsluit. Hij is een voorstander van deskundigheid in de zin van 'le goût de la perfection' binnen een brede bedding, waarin de grote hoofdstroom ook plaats blijft bieden aan de murmelende beken die hem aanvullen en voeden.

N15 Dit is een deel van het sonner 91 van William Shakespeare in de vertaling van H.J. de Roy van Zuydewijn ("William Shakespeare. De sonetren” ISBN 902953715 9, De Arbeiderspers).

Thy love is better than high birth to me,

Jouw liefde is meer dan hoge afkomst waard Richer than wealch, prouder than garments' cost, meer waard dan geld, meer dan de mooiste kleren, Of more delight than hawks or horses be;

And having thee, of all men's pride I boast -

meer dan ' $t$ plezier van haviken of paard; mer jou kan ik eenieders trots trotseren.

N16 "Haec olim meminisse iuvabit": is zin 1,203 uit de Aeneis van Vergilius en luidt in feite volledig "Forsan et haec olim meminisse iuvabit", vrij vertaald "Misschien zal het eens een genoegen zijn ook hieraan terug te denken".

$\mathrm{N} 17$ "Il faut culciver notre jardin", in vertaling "We moeten onze tuin bewerken", is de beroemde slotzin van Candide, het toneelstuk van François-Marie Arouet seigneur de Voltaire (1694-1778). Dit stuk vertelt het verhaal van Candide die de halve wereld bereist en in de gekste avonturen verwikkeld raakt. Voltaire laat Candide ergens in het stuk zeggen: "Het beste dat we op deze aarde kunnen doen, is haar bewerken". In de geest van Voltaire kan 'het bewerken van onze tuin' niets anders zijn dan een oproep op de verantwoordelijkheid van ieder mens onze planeet aarde verder te beschaven. Voor hem is het enige wat telt op deze aarde het geluk van de mensen, maar geluk is voor hem onlosmakelijk verbonden mer werken. In die geest betekent dus "We moeten onze tuin bewerken" de wereld leefbaar maken voor onszelf en onze medemens. 


\section{Literatuur}

L1 Breasted JH: The Edwin Smich Surgical Papyrus. Published in facsimile and hieroglyphic transliteration with translation and commentary. Chicago, University Press, 1930.

L2 Budge J: Uber den Einfluss des Nervensystems auf die Bewegung der Blase. Zeitschr. f. rationelle Medizin, 21: 1, 1864.

L3 Elliott TR: The innervation of the bladder and urethra. ]. Physiol. (Lond), 35: 369445, 1907.

L4 Barrington FJF: The nervous mechanisms of micturition. Quart. J. Exp. Physiol., 8:33, 1915.

L5 Young $\mathrm{HH}$, Wesson MB: The anatomy and surgery of the trigone. Arch. Surg., 3: 1, 1921.

L6 Lapides J: Structure and function of the internal vesical sphincter. J. Urol., 80:341, 1958.

L7 Woodburne RT: Structure and function of the urinary bladder. J. Urol., 84: 79, 1960.

L8 Gosling JA, Dixon JS, Lendon RG: The auconomic innervation of the human male and female bladder neck and proximal urethra. J. Urol., 118:302-305, 1977.

L9 Head H, Riddoch G: The automatic bladder, excessive sweating and some other reflex conditions in gross injuries of the spinal cord. Brain, 40: 188, 1917.

L10 Denny-Brown D, Robertson EG: The state of the bladder and its sphincters in complete transverse lesions of the spinal cord and cauda equina. Brain, 50: 397, 1933.

L1 1 Dubois P: Uber den Druck in der Harnblase. Arch. Klin. Med., 17: 148, 1876.

L12 Rose DK: Cystometric bladder pressures determination: their clinical importance. J. Urol., 17: 484, 1927.

L13 Bradley WE, Clarren S, Shapiro R, Wolfson J: Air cystomerry. J. Urol., 100:451-455. 1968.

L14 Petersen I, Franksson C: Electromyographic study of the striated muscles of the male urethra. Br. J. Urol., 27:148, 1955.

L15 Badr G, Carlsson CA, Fall M, Friberg S, Lindstrom L, Ohlsson B: Cortical evoked potentials following stimulation of the urinary bladder in man. Electroencephal. Clin. Neurophysiol., 54: 494, 1982.

L16 Drake WMJr: The uroflowmeter: an aid to the study of lower urinary tract. J. Urol., 59: $650,1948$.

L17 v Garreles B: Analysis of micturition. A new method of recording the voiding of the bladder. Acta Chir. Scand., 112: 326, 1956.

L18 Scott FB, Quesada EM, Cardus D: Studies on the dynamics of micturition: observations on healthy men. J. Urol. 92:455-463, 1964.

L19 Enhörning G, Miller E, Hinman FJr: Urethral closure studied with cine roentgenography and simultaneous bladder-urethral recording. Surg. Gynecol. Obstet., 118: 507, 1964.

L20 Zinner NR, Ritrer RC, Sterling AM, Harding DC, Baker DW: Clinical applications of drop spectrometry as a non-obstructive, non-interfering method for analyzing hydrodynamic properties of human urination. J. Urol., 102: 485-489, 1969.

L21 Bors E: A simple sphincteromerer. J. Urol., 60:281, 1948. 
L22 Enhörning G: Simultaneous recording of intravesical and intraurechral pressure. Acta Chir. Scand. Suppl: 267, 1961.

L23 Brown M, Wickam JEA: The urethral pressure profile. Br. J. Urol., 4: 211-2I7, 1969.

L24 Asmussen $M$, Ulmsten $U$ : Simultaneous urethro-cytometry with a new technique. Scand. J. Urol. Nephrol., 10: 7-11, 1976.

L25 Guttmann L: Spinal cord injuries. Comprehensive management and research. Blackwell Scientific publications, Oxford/London/Edinburgh/Melbourne, 1973.

L26 Guteman L: The value of intermittent catheterisation in the early mangement of traumatic paraplegia and tetraplegia. Paraplegia, 4: 63-83, 1966.

L27 Lapides J, Diokno AC, Silber SJ: Clean, intermittent self catheterisation in the treatment of urinary tract disease. J. Urol., 107: 458-461, 1972.

L28 Kegel AH: Progressive resistance exercise in the funcrional restoration of perineal muscles. Am. J. Obstet. Gynecol., 56(2): 238, 1948.

L29 Caldwell KP: The electrical control of sphincter incompetence. Lancet, 2: 174, 1963.

L30 Fall $M$, Erlandson BE, Sundin T, Waagstein F: Intravaginal electrical stimulation. Clinical experiments on bladder inhibition. Scand. J. Urol. Nephrol., 44: 41-48, 1978.

L31 Boyce WN, Lathem E, Hunt LD: Research related to the development of an artificial electrical stimulator for the paralyzed bladder. J. Urol., 91: 41-46, 1964.

L32 Brindley GS: Experiments direcred towards a prosthesis wich controls the bladder and the external sphincter from a single site of stimulation. Proc. Biological Engineering Society, 46th Meeting, Liverpool, 1972.

L33 Tanagho EA: Neural stimulation for bladder control. Seminars in Neurology, 8(2): 170-173, 1977.

L34 Abrams P, Blaivas JG, Stanton SL, Anderson JT: ICS first report on the standardisation of terminology of lower urinaty tract function. Br. J. Urol., 48: 39-42, 1976.

L35 Van Kerrebroeck PhEV, Koldewijn EL, Scherpenhuizen S, Debruyne FMJ: The morbidity due to lower urinary tract function in spinal cord injury patients. Paraplegia, 31, 320-329, 1993.

L36 Van Kerrebroeck PhEV: Micrurition discurbances in Multiple Sclerosis: diagnostic and treatment algorithm. Sexuality and Disability, 14, 13-19, 1996.

L37 Koldewijn EL, Rosier P, Meuleman EJH, Debruyne FMJ, Van Kerrebroeck PHEV: Predictors of success with neuromodulation in lower urinary tract dysfunction. Results of trial stimulation in 100 parients. J. Urol., 152, 2071-2075, 1994.

L38 Fowler CS, Van Kerrebroeck PhEV, Nordenbo A, Van Poppel H: Treatment of lower urinary tract dysfunction in patients with multiple sclerosis. J. Neurol., Neurosurg. and Psych., 55, 986-989, 1992.

L39 Van Kerrebroeck PhEV, van der Aa HE, Bosch JLHR, Koldewijn EL, Vorsteveld JHC, Debruyne FMJ and the Dutch Study Group on Sacral Anterior Root Stimulation: Sacral rhizotomies and electrical bladder stimulation in spinal cord injury. Part I: clinical and urodynamic analysis. Eur. Urol., 31:263-271, 1997.

L40 Van Kerrebroeck PhEV, Koldewijn EL, Rosier P, Wijkstra H, Debruyne FMJ: Results of the treatment of neurogenic bladder dysfunction in spinal cord injury by sacral posterior root thizotomy and anterior sacral root stimulation. J. Urol., 155:1378-1381, 1996.

L41 Rijkhoff NJM, Wijkstra H, Van Kerrebroeck PhEV, Debruyne FMJ: Selective detrusor activation by electrical sacral nerve root stimulation in spinal cord injury. J. Urol., 157:1504-1515, 1997. 
L42 Wielink G, Essink-Bot ML, Van Kerrebroeck PhEV, Rutten FFH and the Dutch Study Group on Sacral Anterior Roor Stimulation: Sacral rhizotomies and electrical bladder stimulation in spinal cord injury. Part II: cost-effectiveness and quality of life analysis. Eur. Urol., 31:441-446, 1997.

L43 Kinder MV, Gommer ED, Waalwijk van Doorn ESC, Janknegt RA: Multi-electrode recording of a "clean" detrusor electromyogram. NeuroUrol. Urod., 15-4:187-288, 1996.

L44 Kinder MV, Waalwijk van Doorn ESC, Gommer ED, Janknegt RA: Surface detrusor EMG in healthy volunteers. NeuroUrol. Urod., 15-4:288-290, 1996.

L45 Bemelmans BLH, Van Kerrebroeck PhEV, Notermans SLH, Wijkstra H, Debruyne FMJ: Motor evoked porentials from the bladder on magnetic stimulation of the cauda equina: a new technique for investigation of autonomic bladder innervation. J. Urol., 147, 658-661, 1992.

L46 Van Kerrebroeck PhEV, Debruyne FMJ: World wide experience with the FinetechBrindley sacral anterior root stimulator. NeuroUrol. Urod., 12, 497-503, 1993. 